\title{
FISCAL CONSEQUENCES OF MONETARY INTEGRATION WITHIN THE COMMON ECONOMIC AREA: THE CASE OF BELARUS, KAZAKHSTAN, AND RUSSIA
}

\section{Ainura Uzagalieva}
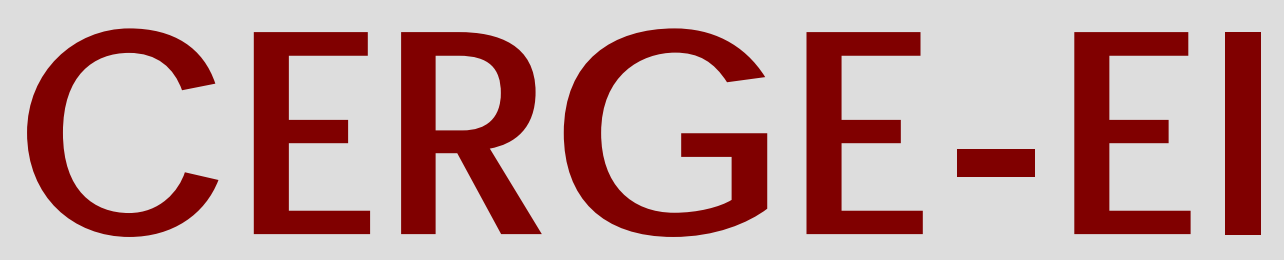

Charles University Centerfor Economic Research and Graduate Education Academy of Sciences of the Czech Republic Ec onomic s Institute 


\title{
Working Paper Series \\ 254 (ISSN 1211-3298)
}

\section{Fiscal Consequences of Monetary Integration within the Common Economic Area: the Case of Belarus, Kazakhstan and Russia}

Ainura Uzagalieva

\author{
CERGE-EI \\ Prague, April 2005
}


ISBN 80-7343-047-9 (Univerzita Karlova v Praze, CERGE)

ISBN 80-7344-036-9 (Národohospodářský ústav AV ČR, Praha) 


\title{
Fiscal Consequences of Monetary Integration within the \\ Common Economic Area: \\ the Case of Belarus, Kazakhstan and Russia
}

\author{
Ainura Uzagalieva* \\ Center for Economic Research and Graduate Education (CERGE-EI) \\ P.O. Box 882, Politických vězňů 7 \\ 11121 Praha 1, Czech Republic
}

\begin{abstract}
The aim of this paper is to analyze the possible impact of planned monetary integration on public sector revenues from seigniorage in three countries: Belarus, Kazakhstan and Russia. Using the concept of total gross seigniorage, we investigate the main sources and uses of the central bank revenues in these countries. Special attention is given to the role of seigniorage revenues in financing public sector expenditures. Amounts of yearly transfers from central banks to the state budget in Belarus, Kazakhstan and Russia are evaluated, and the size of potential gains and looses in seigniorage revenues under different scenarios of monetary integration are estimated.
\end{abstract}

\begin{abstract}
Abstrakt
Tento článek analyzuje potencionální vliv plánované monetární integrace na př́jmy veřejného sektoru z ražebného (seigniorage) v Bělorusku, Kazachstánu a Rusku. Pomocí konceptu celkového hrubého ražebného (total gross seigniorage) zkoumáme hlavní zdroje a použití př́ijmů centrální banky $\mathrm{v}$ těchto zemích. Klademe zvláštní pozornost na roli př́ijmů $\mathrm{z}$ ražebného ve financování veřejných výdajů. Hodnotíme roční výši transferů centrálních bank do státního rozpočtu v Bělorusku, Kazachstánu a Rusku, a odhadujeme výši potencionálních zisků a ztrát ražebních př́ijmů $\mathrm{v}$ závislosti na různých scénáŕích monetární integrace.
\end{abstract}

Keywords: seigniorage, monetary integration, transition economies

JEL Classification: E 52, E56

*I am grateful to Jacek Cukrowski, Randal Filer, Sergej Slobodyan, Lubomír Lízal, and Mercury RobinEliece for useful comments and suggestions. 


\section{Introduction}

Given the limited success of market reforms in individual economies, tendencies to coordinate economic policies among Commonwealth Independent States (CIS) countries have strengthened in recent years. The most prominent example of such a trend is the summit meeting of CIS presidents organized on September 18, 2003 in Yalta, where a project for the creation of an integrated economic space including Belarus, Kazakhstan, Russia, and Ukraine, called the Common Economic Area (CEA), was signed. The CEA is going to be created in three stages and will influence the main priorities of economic development set for 2003-2010. The first stage will focus on creating the necessary conditions for a free trade regime and will be implemented by changing legislation on cross-border goods transfers and simplifying customs procedures. In the second stage, a union with common tariffs, joint competition policy, and a single customs code will be established. The third stage will focus on removing customs borders among the countries and on establishing a common trade zone with free capital, service and labor flows.

Preferences in macroeconomic management are given to gradual economic convergence. According to the draft Concept of CEA, ${ }^{1}$ convergence will be achieved through economic regulations and common actions in foreign trade, fiscal and monetary policy. Potential candidates who meet the necessary criteria ${ }^{2}$ will join the single currency area. Thus, in the near future monetary integration among some of the CIS countries can be expected. Belarus and Russia have already taken the first step in this process. Both countries signed an agreement on the Common Emission Center (CEC) of the RussiaBelarus Union on November 30, 2000, stating that a new currency, the ruble of the Union State, will be introduced as legal tender in Russia and Belarus starting from January 1, 2008. During an intermediate period, from January 1, 2006 to December 31, 2007, the Russian ruble will circulate as a single currency in both countries. Signing the Government Decree on the Concept of Financial System Development by the government of Kazakhstan on July 28, 2003 was another important step towards monetary integration.

\footnotetext{
${ }^{1}$ See Concept on the Establishment of the CEA of September 19, 2003, draft (in Russian).

${ }^{2}$ The criteria include: inflation - no more than 5\%; state debt - no more than 50\%; external debt - no more than $30 \%$; and budget deficit - no more than $3 \%$ of GDP (see the Decree on the Concept of Financial
} 
The decree indicates that the gradual merging of the financial system of Kazakhstan to a common payment system in CIS (either within the Eurasian Economic Community $(\mathrm{EEC})^{3}$ or within another system of integration) as one of the key priorities. According to the Concept of CEA, Kazakhstan intends to start preparing for joining a single currency area in 2005. It is assumed that monetary integration will take place in 2011.

Expected monetary integration among three CIS countries raises important issues related to fiscal and monetary policies since the influence of factors, which underlie the inefficiency of the tax system and revenue motives for monetary expansion, is strong. A large shadow economy, which is not possible to tax, and underdeveloped capital markets, at which governments cannot sell large amounts of treasury bills, strengthen the publicfinance motives of seigniorage obtained by a central bank (Koreshkova 2003). The creation of a common monetary area (CMA) will deprive the national policymakers of monetary policy instruments ${ }^{4}$ and change the redistribution of seigniorage revenues. Consequently, it will have budgetary consequences with different patterns and magnitudes across the countries since the size of the seigniorage, which is transferred by the central banks to their governments, is not the same in the countries considered. In this respect, it is important to investigate the magnitude of seigniorage transfers to the state budget in a pre-integration period, analyze the country-specific features of institutional and monetary environment, and estimate the welfare impact of monetary integration. These issues are critical because they would play a crucial role in negotiations among the member states for the rules regulating the distribution of seigniorage wealth within CMA.

The importance of seigniorage revenues in the context of monetary integration was already recognized in a number of studies related to the creation of common currency area in the European Union (EU) (see Cukrowski and Fischer 2002; Feist 2001; Schobert 2001; Sinn and Feist 1997, 2000). In particular, due to cross-country differences in banking regulations and the level of accumulated seigniorage wealth, monetary integration will

System Development by the Government of Kazakhstan of July 28, 2003, in Russian).

3 The members of EEC are Belarus, Kazakhstan, Kyrgyzstan, Russia, and Tajikistan.

${ }^{4}$ Open market operations, discount rate, and reserve requirements. 
result in large welfare transfers among the member states of European Monetary Union (EMU) (Sinn and Feist 1997). The authors found that among fifteen EU member states, countries with a more liberal banking sector like France and the UK (e.g. with low reserve-deposit ratio) would gain, while countries like Germany, Austria, and Spain would loose as they are characterized by smaller liberalization of banking sectors with high reserve requirements. Further studies (Cukrowski and Fischer 2002) that focused on new EU member states suggest that if the current mechanism of seigniorage wealth distribution does not change, virtually all countries, except the Czech Republic, will gain by joining the euro zone. This can be explained by a seigniorage distribution mechanism (see Section 5), in particular, by the fact that the new EU member states are relatively poor compared to the countries of the euro area, and therefore, their population shares will be larger than their respective GDP shares in the EMU. Larger capital shares in the European Central Bank (ECB) relative to the share of a country's seigniorage wealth in a common pool will allow them to receive a larger portion of it.

The general economic environment as well as the institutional features of central banks in CIS countries are different from that in EMU accessing countries. So, the main components of the central bank revenues and welfare impact of monetary integration in the conditions of CIS countries deserve special attention. The aim of this study is to analyze sources and uses of the central bank's seigniorage in Belarus, Kazakhstan, and Russia, taking into account specific features of the monetary environment as well as central bank institutional arrangements and the potential welfare effect caused by monetary integration in each country. The analysis is based on official documents (e.g. financial sector legislation and the annual reports of the central banks) characterizing central bank operations during 1997-2003. Potential welfare gains or losses from monetary integration are estimated assuming three possible mechanisms of seigniorage wealth redistribution among the member states of CMA: (1) redistribution proportional to accumulated seigniorage wealth; (2) redistribution according to the mechanism used in the EMU; and (3) redistribution according to economic potential of the member states. 
The remaining part of the paper is structured as follows. Section 2 highlights the concept of seigniorage revenue and recent evidence of the seigniorage phenomenon in transition economies. Section 3 describes in detail the methods of measuring seigniorage distinguishing its four main sources and uses. Section 4 discusses the empirical results of estimating seigniorage revenues in Belarus, Kazakhstan, and Russia and compares the process of seigniorage generation and allocation in these countries. Section 5 considers possible schemes of a seigniorage wealth distribution mechanism in an integrated economy and estimates the welfare effect in each member country. Section 6 concludes.

\section{The concept of seigniorage revenues, recent evidence in transition economies}

Theoretical and empirical studies (Fischer 1982; Friedman 1971; Feige, Faulend, Sonje, Sosic 2000; Schobert 2001) consider seigniorage revenues as the main economic argument in favor of national currencies. Fischer (1982) regards seigniorage as one of the most important factors that determine the desire of a country in choosing a domestic currency over a foreign one. The argument is also important for countries considering either to integrate in monetary unions or to adopt official dollarization (or eurization, rublification) by substituting their national currencies (Feige, Faulend, Sonje, and Sosic 2000; Schobert 2001). The basic concepts of seigniorage include: a conventional monetary concept (Fischer 1982; Friedman 1971; Haslag 1998; Schobert 2001); an opportunity cost concept (Honohan 1996; Klein and Nuemann 1990; Schobert 2001); a fiscal dominance concept (Honohan 1996; Sargent and Wallace 1981), and a fiscal concept (Drazen 1985; Honohan 1996; Klein and Neumann 1990; Neumann 1996; Schobert 2001).

The monetary concept is based on the idea that a government can finance its spending through direct loans from a central bank, creating high-powered money in the form of non-interest bearing currency. The intuition behind this concept is the maximization of government revenues. Friedman (1971) shows that by knowing the money demand function, one could determine the optimal (seigniorage maximizing) rate of money growth. De Haan, Zelhorst and Rouken (1993), however, demonstrate that this approach is inappropriate for transition and developing countries both from theoretical and 
empirical points of view. First of all, due to small money stock held by the transition or developing economy, the tax base and tax revenues are low. So, in order to obtain the required amount of seigniorage revenue, the central bank should always maintain high and increasing money growth, resulting in high inflation rates. Klein and Neumann (1990) also criticized this approach because it does not consider the legal, institutional, and operational specificity of the central bank and thus, can give misleading results.

The opportunity cost concept is associated with an optimal tax approach which implies that the higher the costs of collecting taxes the higher the seigniorage is. Under this concept, the government finances its spending through issuing and selling interest bearing bonds rather than through issuing non-interest bearing currency. This causes an increase in high-powered money because in order to keep the real value of money constant against inflation money holders should increase their nominal balances. In comparison to the monetary concept, this framework takes into account proceeds obtained by the central banks on a stock of assets accumulated from the outstanding quantity of money. The main critique comes from the fact that there are other sources of financing the budget besides issuing bonds when seigniorage is not available, so lost revenues from seigniorage could lead to a reduction in government expenditures and/or an increase in foreign borrowing. Therefore, the opportunity cost concept should be assessed on a wider economic perspective including the loss of output due to lower government expenditures and fewer tax revenues or increases in foreign debt (Klein and Neumann 1990; Schobert 2001).

The fiscal dominance concept was originally described by Sargent and Wallace (1981). They distinguish situations of fiscal and monetary dominance. When monetary policy is dominant, the central bank sets its monetary policy independently and determines the size of seigniorage revenue it would supply to the government freely while fiscal authorities face constraints imposed by the demand of government bonds. However, when a fiscal policy dominates, the monetary policy is weak and becomes endogenous to government in the sense that it can set fiscal plans, determine the required level of seigniorage for financing the budget revenues irrespective of monetary policy objective, and can strongly influence decision-making in the central bank. In this case, monetary authorities face constraints imposed by the demand of government bonds. Consequently, 
the money supply is unable to have an impact on the real deficit net of interest payments, and the real interest rate can exceed the economic growth rate, which will result in a rapid expansion of the government debt. However, when the debt ratio reaches a certain level, the public will not be able or willing to absorb the additional government debt. Then budget deficits have to be financed by borrowing from commercial banks and/or from abroad, which is the case in transition economies. However, because the willingness of commercial banks and foreigners to buy newly-issued government debt is also limited, monetary authorities will be forced to finance the budget deficit by money creation. This concept appears broader and seems more applicable for transition countries.

The fiscal concept joins all the mentioned approaches into a single approach as a general measure of seigniorage revenue (Drazen 1985, 1989). Drazen suggests that each of the above-mentioned measures is a special case which relates to specific monetary and fiscal policy experiments and conditions. He distinguishes between the financing and taxation aspects of monetary expansion and focuses on the net revenues that fiscal authorities receive from monetary operations. These operations are related not only to the creation of a monetary base but also to the management of the central bank. It also takes into account previous monetary expansions, which continue to accrue government assets that provide present yields. This difference was especially stressed by Cukrowski and Fischer (2002); Cukrowski and Janecki (1998); Cukrowski and Stavrev (2001); Klein and Neumann (1990) and Neumann (1996) and developed further as a total gross seigniorage concept. In particular, Neumann (1996) showed formally that this concept is a generalization of all others and allows one to analyze seigniorage in the broadest possible sense as the sum of all revenues resulting from the monopoly power of the central bank to manage its base money.

The variety of seigniorage concepts determine different ways of measuring seigniorage revenues. Also, the process of generating and using seigniorage revenues in a particular country depends on country-specific features, in particular, on the legal, institutional, and operational arrangement of the central bank (Drazen 1985). The actual independence of the central bank is especially important in this aspect since an independent central bank can prevent government from financing inflationary budget 
expenditures. Empirical evidence shows that in CIS economies, the institutional and monetary environment of central banks are characterized by a limited degree of independence (Maliszewski 2000), although legally almost all of them are considered independent. Cukierman, Edwards, and Tabellini (1989) also noted that due to weak tax enforcement, the governments may rely heavily on seigniorage revenues in financing budgets even if such a privilege is restricted by legislation. Later, Cukierman (1992) again stressed that de jure independence in transition economies does not necessarily imply de facto independence, i.e., legal protection is not necessarily binding due to poor compliance with the law.

Maliszewski (2000) investigated the degree of central bank independence in 20 transition economies ${ }^{5}$ by evaluating indexes of political and economic independence proposed by Grilli, Masciandaro, and Tabellini (1991). Political independence is defined as the ability of the central bank to choose the final goal of its policy. This measure is determined by the relationship of the central bank with its government, the procedure of appointing the board of the central bank, and a formal goal of the central bank. According to Maliszewski (2000), the central banks of Belarus, Russia, and Ukraine have the least political independence among CIS countries with the political indices ${ }^{6}$ estimated at 5, 5, and 3, respectively. Limitations on the amount of credit from the central bank to its government to correspond with key factors determining economic independence are almost non-existent in Belarus and the Ukraine. Although legislation in Russia and Kazakhstan prohibits the central banks to finance their governments, in some cases this requirement is overlooked. Maliszewski (2000) stressed that the problem of actual central bank independence is much wider than legal independence. Hochreiter, Rovelli, and Wincler (1996) also pointed out that it is never clear how much and to what extent the central banks in less-developed countries are actually independent. Obviously, given the

\footnotetext{
${ }^{5}$ The sample covers former Soviet countries: Armenia, Belarus, Estonia, Georgia, Kyrgyzstan, Latvia, Lithuania, Moldova, Russia, and the Ukraine and Central European countries: Albania, Bulgaria, Croatia, Czech Republic, Hungary, Macedonia, Poland, Romania, Slovakia, Slovenia.

${ }^{6}$ The index of political and economic independence ranges from 2 to 9 in this study. In countries with sound political independence of the central bank, this index is high (e.g. 8 in Kyrgyz Republic, 8 in the Czech Republic, and 7 in Poland).
} 
different degree of central bank independence across countries and consequently, the variety of economic environments, the practice of obtaining seigniorage revenues varies as well.

We should note that in developed economies, where the central banks are characterized by a high degree of independence, normally, seigniorage is not used for financing government expenditures; rather it reflects changes in monetary policy and usually ranges between $0.5-1.5 \%$ of GDP (Click 1998). In contrast, the more underdeveloped a country is, the less independent its central bank, and the less independent the central bank is, the higher the role of seigniorage revenues in financing government budgets. For example, the size of seigniorage in several Southern European countries reported as the share of GDP varies between $2 \%$ and $4 \%$ (Horrendorf 1997). In a pool of 90 developing countries, the annual average of this indicator reached almost $9 \%$ during 1962-1985 (De Haan, Zelhorst, and Roukens 1993). These findings confirm the argument of Cukierman, Edwards, and Tabellini (1989) that in highly indebted poor countries, seigniorage is high as well.

\section{Total gross seigniorage revenues, components, and measures}

As mentioned in Section 2, in order to estimate and compare seigniorage revenues across countries, one has to take into consideration the details of legal, institutional, and operational arrangements of the central bank and thus use of the concept of the total gross seigniorage proposed by Neumann (1996). This approach allows one to analyze seigniorage in the broadest possible sense as the sum of all revenues resulting from the monopoly power of the central bank to manage base money. However, its implementation requires a very detail analysis of central bank operations taking into account countryspecific features.

According to the approach of Nuemann, the total gross seigniorage $(s)$ is specified as

$$
s=s^{M}+s^{I}+s^{O P}+s^{R I} .
$$


The first term of this expression, $s^{M}$, denotes monetary seigniorage, which is a change in the real, i.e. deflated by the general price level, stock of monetary base $(\Delta M)^{7}$. Monetary seigniorage is defined as

$$
s^{M}=\frac{\Delta M}{p}=\frac{\Delta M}{M} m,
$$

where $p$ denotes the general price level and $m$ - real balances. The second term, $s^{I}$, denotes net interest revenues accrued on the stock of non-government debt deflated by the general price level, and it is expressed as

$$
s^{I}=\frac{i^{P} A^{P}+i^{F} A^{F}}{p},
$$

where $A^{P}$ denotes the net claims of the central bank to domestic private sector and $A^{F}$ - the net foreign assets of the central bank; the terms, $i^{P}$ and $i^{F}$, correspond to nominal interest rates, respectively. The third term $\left(s^{O P}\right)$ describes net revenues from central bank's operations deflated by the general price level

$$
s^{O P}=\frac{G}{p},
$$

where $G$ stands for net revenue. Finally, $s^{R I}$ denotes book gains due to a change in the value of net foreign assets resulting from exchange rate movements. This term is defined as

$$
S^{R I}=\frac{L}{p}=\frac{\Delta e A^{F}}{e p},
$$

where $L$ denotes a book gain, and $e$ - exchange rate.

As it was noted by Cukrowski and Janecki (1998); Cukrowski and Stavrev (2001); and Cukrowski and Fischer (2002), empirical studies based on monetary seigniorage concept usually only approximate actual seigniorage flow from the central bank to the government. This stems from two simplified assumptions: one is that the government receives seigniorage revenues irrespective of the legal and institutional regulations existing between the government and the central bank; and another is that the amount of seigniorage revenues transferred to the government is independent of the specificity of the

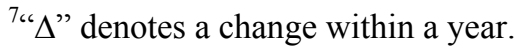


monetary environment. The authors argue that such a simplification does not take into account the cost of money production, which can be very large, ${ }^{8}$ nor the existence of the central bank as a whole. Neumann (1996) shows that the central bank uses seigniorage for covering its expenses on money creation and operating activities $\left(s^{C}\right)$; investments in nongovernment debt $\left(s^{N I}\right)$; transfers to the state budget $\left(s^{G}\right)$; and financing own capital and reserves or payments to third parties $\left(s^{O}\right)$ :

$$
s=s^{C}+s^{N I}+s^{G}+s^{O}
$$

In the expression (6), the costs on money creation and operating activities are defined as the sum of the cost of printing notes $\left(C^{B n}\right)$ and the cost of maintaining operations $\left(C^{C B}\right)$ deflated by the general price level:

$$
s^{C}=\frac{C^{B n}+C^{C B}}{p} .
$$

The central bank holding of non-government debts is defined as the change of the net claim to domestic private sector $\left(\Delta A^{P}\right)$ and the net foreign assets $\left(\Delta A^{F}\right)$ as

$$
S^{N I}=\frac{\Delta A^{P}+\Delta A^{F}}{p} .
$$

The expressions for determining budget financing $\left(s^{G}\right)$ and an increase in central bank capital and reserves are:

$$
\begin{gathered}
S^{G}=\frac{\Delta A^{G}+\left(R^{G}-i^{G} A^{G}\right)}{p}, \text { and } \\
s^{O}=\frac{R^{O}}{p}, \quad \text { respectively. }
\end{gathered}
$$

In the expression (10), $R^{O}$ denotes profit transferred to third parties or used for reserves and capital accumulation.

Following Neumann (1996), the part of the seigniorage transferred to the state budget $s^{G}$ (specified by expression (9)) is called fiscal seigniorage. The government

\footnotetext{
${ }^{8}$ As Klein and Neumann (1990) showed during 1974-1987 about $16.9 \%$ of German monetary seigniorage was used to cover the Bundesbank's operating costs.
} 
receives fiscal seigniorage through: net borrowing from the central bank $\left(\Delta A^{G}\right)$ and taking the profits of the central bank net of interest payments earned on the stock of government debt $\left(R^{G}-i^{G} A^{G}\right)$. Consequently, fiscal seigniorage can be fully determined by expression (9).

\section{Sources and uses of seigniorage in Belarus, Kazakhstan, and Russia (empirical results)}

The concept presented in the preceding section views seigniorage from two important angles: creation and distribution. This section deals with the empirical estimation of the sources and uses of seigniorage in three countries: Belarus, Kazakhstan, and Russia in a period 1997-2003. Specific features of monetary environment and the institutional arrangements of the central banks in each country are described. The sources of the data are International Finance Statistics (IFS) and the annual reports of central banks for the period 1997-2003 which contain the balance sheet records of central bank assets and liabilities and financial statements of income and expenditure of the central banks (see Table 1 in Appendix). The sources and uses of seigniorage revenues are calculated at annual frequency in terms of national currencies and expressed as a fraction of GDP for the purpose of comparison across the countries.

The results of estimations indicate that the size of central bank seigniorage revenues (total seigniorage) is quite high in all countries under consideration (see Table 2 in Appendix). The average value of seigniorage obtained by the central banks of Belarus, Kazakhstan, and Russia during 1997-2003 are 4.3\% of GDP, 5.1\% of GDP, and 5.7\% of GDP, correspondingly. These values are larger than the average size of seigniorage estimated during 1971-1990 in 78 countries $^{9}$ (Click 1998), which rank from less than $0.5 \%$ GDP to about $4.0 \%$ of GDP.

\footnotetext{
${ }^{9}$ Click (1998) investigated seigniorage in a cross-section of 90 developed and developing countries over the period 1971-1990. Countries with the largest size of seigniorage are Israel with $14.8 \%$ of GDP, Yugoslavia with $11.9 \%$ of GDP, Chile with $10.3 \%$ of GDP, Argentina with $9.7 \%$ of GDP, and Nicaragua with $7.9 \%$ of GDP.
} 
The year by year change of seigniorage in Belarus, Kazakhstan, and Russia shows that in all three countries it increased drastically in 1998-1999, approaching the upper boundary (10.1\% of GDP) in the ranking of 42 developing countries by the average of seigniorage during 1974-1985 (De Haan, Zelhost, and Roukens 1993). So, the total seigniorage reached 8.5\% of GDP in 1998 in Belarus; in Kazakhstan - 6.7\% of GDP in 1999; and in Russia - 9.8\% of GDP in 1998. This was the result of a financial crisis in Russia in 1998, where the annual inflation rate reached $84.4 \%$, currency depreciated by 4 times, foreign reserves declined by $31.3 \%$, output fell by $4.6 \%$, and the budget deficit was to $8.2 \%$ of GDP. The Russian crisis heavily influenced the economies of Belarus and Kazakhstan, causing during the year, a very large decline in foreign trade (by 19.6\% and $7.0 \%$, respectively); an exchange rate depreciation (by 5.6 and 1.5 times, respectively); and an increase in the annual inflation rates (to $351.2 \%$ and $17.8 \%$, correspondingly).

The comparison of total seigniorage revenues suggests that in 1997-1999, the manner of collecting seigniorage revenues by the central banks was similar across the countries under consideration. Namely, in this period monetary seigniorage is a main part of seigniorage revenues. For example, at the end of 1999 the monetary seigniorage component reached $74.1 \%$ of the total seigniorage revenues in Belarus; $34.0 \%$ - in Kazakhstan $^{10}$; and 85.8\% - in Russia. During 1998-1999 the book gain component, which is just an increase in the recorded value of foreign reserves in terms of national currencies, resulting from an exchange rate depreciation was also very large reaching $26.3 \%$ of total seigniorage in Belarus; 52.8\% - in Kazakhstan; and 41.7\% - in Russia.

In all subsequent years (e.g. 2000-2003), however, the ways of obtaining total seigniorage differs across the countries. The government sectors of Kazakhstan and Russia, for instance, increased the amounts of their oil-related funds held in their central banks which, correspondingly, contributed to the decrease of the government debt. The government funds contributed to the total seigniorage revenues with about $3.8 \%$ of GDP in Kazakhstan and $1.2 \%$ of GDP in Russia on average during 2000-2003. The total

\footnotetext{
${ }^{10}$ A relatively small size of monetary seigniorage in the total seigniorage revenue of Kazakhstan in 1999 was due to a large increase in the book gain component of seigniorage (it reached $52.8 \%$ of total seigniorage). This was resulted by strong exchange rate depreciation (by $52.8 \%$ ).
} 
seigniorage of Belarus declined during these years from 5.3\% of GDP in 1999 to $2.2 \%$ of GDP in 2003 (see Table 2 in Appendix) due to a strict monetary policy (monetary seigniorage declined from $3.9 \%$ of GDP in 1999 to $1.6 \%$ of GDP in 2003).

The structure of seigniorage by distribution, on the contrary, is characterized by a more diverging pattern across countries. While the central bank of Belarus was using seigniorage revenues mainly for financing the state and public sectors throughout the whole period considered, the central banks of Russia and Kazakhstan were using it, especially after the crisis of 1998, for their investing activities and financial reserves and capital. In order to examine to what extent the central banks were financing their governments, a more detailed overview of seigniorage uses with a brief description of the general economic, monetary and legal environment in each country are presented below.

\subsection{Belarus}

Belarus is a country located in western CIS with a population of about 9.9 million and a territory of $207.6 \mathrm{sq} . \mathrm{km}$. The most important part of the production process is the manufacturing industry (32.6\% of GDP). Transition started in Belarus at the beginning of the 1990s similar to other CIS countries; however, the reform process has been significantly slower due to a strong resistance of the government to radical economic reforms (Liberati 2001). The attitude of the government to market reforms has been emphasized in the guidelines of social and economic development set for 1996-2005. ${ }^{11}$ The document stresses the importance of policies designed "against market shocks" (e.g. social protection, setting wages and production targets by the state, enterprise support, price controls, and directed credits) in achieving the main objectives of the government: to improve the living standards and build a socially-oriented market economy.

After decline at the beginning of the 1990s, the economy of Belarus started to revive in 1996 when the real GDP growth rate reached 2.8\%. The expansion of the industrial sector, ${ }^{12}$ which was stimulated by strong domestic demand, and trade

\footnotetext{
${ }^{11}$ See Social and Economic Development Program for 1996-2005 of the Government of the Republic of Belarus.

${ }^{12}$ See Annual Report of NBRB for 1998.
} 
contributed to high rates of real GDP growth in 1997 and 1998 as well with $11.4 \%$ and $8.4 \%$, respectively. During 1999-2002, the economy was growing at about $4.7 \%$ on average, and in 2003 the GDP growth rate reached 6.8\%, accounting for more than $90 \%$ of the 1990's level. Persisting soft budget constraints and a high degree of state intervention in the economy significantly slow down the speed of reforms. For example, the share of the private sector in GDP and average transition scores reported by EBRD on the reform process $^{13}$ are the lowest (about 25\%, 2.4 and 1.5, respectively) among all transition economies excluding Turkmenistan, while a shadow economy ${ }^{14}$ is in its increasing path. According to Schneider (2002), the shadow economy measured by physical input (or electricity consumption) and a multiple-cause-multiple-indicator (MIMIC) ${ }^{15}$ methods increased in Belarus from 34.0\% of GDP in 1990-1993 to 47.1\% in 2000-2001, on average.

There are substantial macroeconomic imbalances in the economy of Belarus today. It is especially true in the external sector where the balance of payment situation remains difficult with a large current account deficit (527 $\mathrm{mln}$. USD or $3 \%$ of GDP); a huge external debt (1438 mln. or $8.2 \%$ of GDP); and a trade deficit (1612 mln. USD or $9.2 \%$ of GDP). ${ }^{16}$ The budget deficit is recorded at $1.2 \%$ of GDP in 2003 ; however, the quasi-fiscal deficit $^{17}$, which reflects large directed credits to the public sector and state enterprises, is high. It reached about $11.1 \% \mathrm{GDP}^{18}$ in 1999 while the official budget deficit was recorded

\footnotetext{
${ }^{13}$ Reform process is reported in two dimensions: initial-phase reforms (e.g. price liberalisation, foreign exchange and trade liberalisation, and small-scale privatisation) and second-phase reforms (e.g. large-scale privatisation, governance and enterprise restructuring, competition policy, infrastructure reforms, banking and interest rate liberalisation, and non-banking institutions) (see EBRD Transition report 2004).

${ }^{14}$ The shadow economy is defined as "market-based production of goods and services, whether legal or illegal that escapes detection in the official estimates of GDP" (Schneider 1994).

${ }^{15}$ A MIMIC method is based on the observations of tax evasion rates, work force not covered by social security, the labour participation rate, etc.

${ }^{16}$ See EBRD Transition Report 2004.

${ }^{17}$ Quasi-fiscal activities in a transition economy are defined as the credits of its central bank extended to the public enterprise sector (see Buiter 1997).

${ }^{18}$ See Markiewicz (2000).
} 
at $1.9 \%$ of GDP only. According to the International Monetary Fund (IMF), the size of quasi-fiscal operations has been high in recent years too. However, due to difficulties in obtaining reliable data (information on the deficit of public enterprises is under the direct control of the presidential administration and not available to the public) it cannot be measured precisely. ${ }^{19}$ Therefore, due to quasi-fiscal activities and an expansionary fiscal policy (the government expenditure increased from $44.1 \%$ in 2002 to $46.1 \%$ of GDP in 2003 ), high inflation still remains to be the key problem; the annual inflation rate is $28.4 \%$ in 2003 (see Table 3 in Appendix).

The banking system of Belarus consists of the central bank, named the National Bank of the Republic of Belarus (further NBRB), and commercial banks, about $80 \%$ of which are owned by the state. ${ }^{20}$ The activity and institutional status of the central bank of Belarus is regulated by the Constitution of the Republic of Belarus (further RB), the Banking Code of RB, laws and legal acts of the president of RB, and the Statute of NBRB. NBRB is accountable to the president of Belarus. Legally the institutional status of NBRB is recognized independent from the government and state agencies. However, in practice such independence is very limited both politically and economically. In particular, the chairman of the NBRB, who is appointed by the president, must necessarily be a member of the government. Moreover, in its lending activity NBRB acts not only as the lender of last resort for banks, but also as a creditor to the government ${ }^{21}$, providing it with direct loans in compliance with the budget law.

Data presented in Table 2 (in Appendix) demonstrates that the central bank in Belarus used a relatively large portion of its seigniorage revenues for financing the government budget in the years of 1997-1999. The size of fiscal seigniorage is especially large in 1998 when NBRB transferred to the government the amount equivalent to $5.3 \%$ of GDP. During 1999-2003, the amount of NBRB's fiscal transfers to the government

\footnotetext{
${ }^{19}$ See International Monetary Fund Country Report No. 04/141, May 2004.

${ }^{20}$ See EBRD Transition Report 2004.

${ }^{21}$ See "Banking Code of the Republic of Belarus" passed by the House of Representatives on October 3, 2000 and approved by the Council of the Republic on October 12, 2000.
} 
gradually decreased. It fell from $3.5 \%$ of GDP in 1999 to $1.3 \%$ of GDP in 2001, and in 2002 , it switched from a positive to a negative number $(-1.1 \%$ of GDP) due to the large reduction (by $64.2 \%$ ) of government obligations towards NBRB during the year. The reason for this was that the government of Belarus privatized a gas transporting and distributing company (Beltransgaz) in 2002 under the condition of an agreement with Russia giving to Belarus an access to natural gas from Russian Gazprom at internal prices in Russia. So, an increase in privatization revenues from $1.2 \%$ of GDP to $2.8 \%$ of GDP during the year allowed the government to finance about $72.0 \%$ of its fiscal deficit without relying on the revenues of the central bank. In addition, reforms in the energy sector, namely, an increase in the tariffs of gas and energy for households (by 2.9 times), which were assigned to raise the cost recovery of enterprises, contributed to the increase of tax collections (by $0.3 \%$ of GDP) in 2002. As a result, the net claim of the central bank to the government was reduced during the year.

Difficulties with the balance of payments did not allow the government to rely much on the external sources of budget financing in 2003. So, the net foreign financing of the budget deficit decreased from $15.1 \mathrm{mln}$. USD in 2002 to $-8.8 \mathrm{mln}$. USD in 2003 . Besides, the slow speed of structural reforms and privatization did not allow any improvement the collection of tax revenues and privatization receipts, which increased by $0.1 \%$ GDP only during the year. So, persisting difficulties in the area of government finance caused NBRB to increase the amount of fiscal transfers in 2003 again. It reached $1.0 \%$ of GDP indicating the fact that NBRB is required to provide the government with funds for financing the budget deficit $(1.2 \% \text { of GDP })^{22}$ through either extending direct credits or purchasing government bonds at the primary market or both. The scale of the fiscal seigniorage transferred by NBRB to the government during 1997-2003 is presented in Figure 1.

\footnotetext{
${ }^{22}$ See Law of the Republic of Belarus "On the Budget of the Republic of Belarus” for 1998-2003.
} 


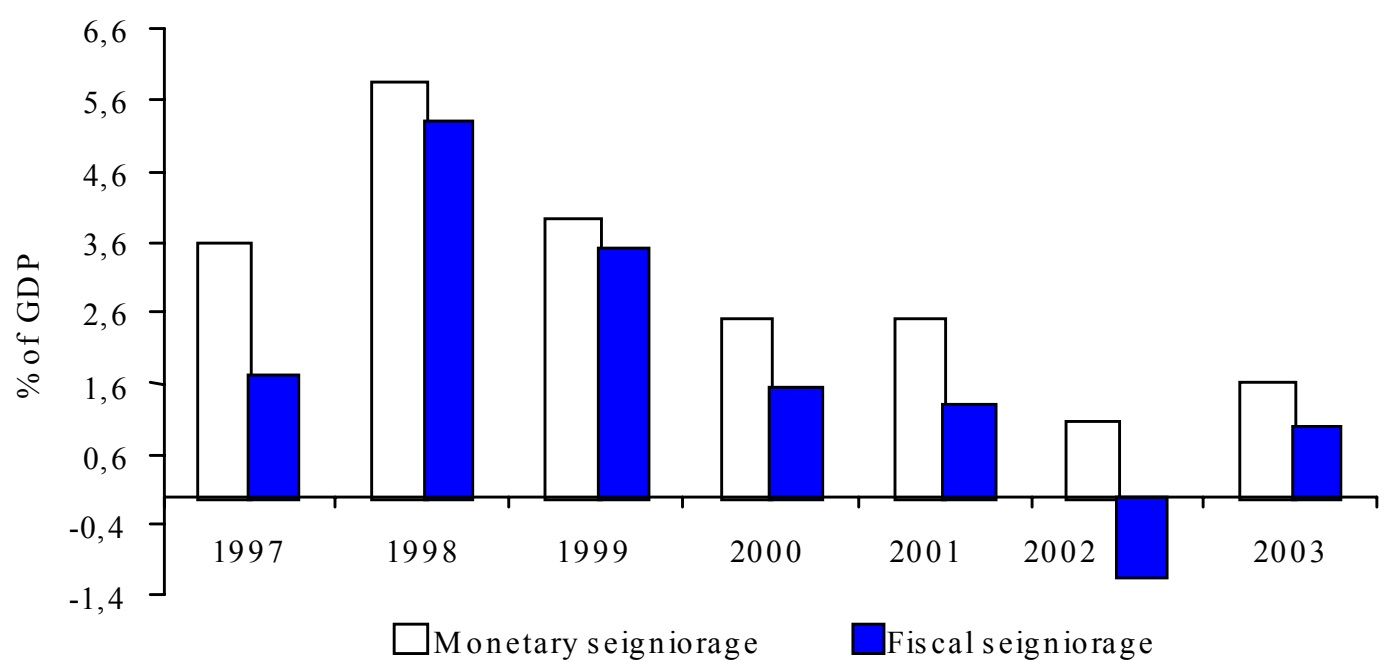

Figure 1. Belarus: monetary and fiscal seigniorage

Figure 1 reveals that NBRB used for financing its budget deficit revenues generated through money creation. Furthermore, as Table 2 shows, NBRB used the largest part of its seigniorage revenues, especially during 1997-1998 (about 3.1\% of GDP), for extending credits to private or the non-governmental sector of the economy. In almost all years except 1999, a primary component of seigniorage use is net investment or an increase in the holdings of the central bank of private (e.g. non-government) domestic and foreign debt.

It needs to be stressed that one has to be very careful when using the word "private" as a descriptor for the net investments of the central bank in non-government debt instruments because the private sector in Belarus includes not only privately owned enterprises, but also state-owned enterprises as well as the household sector. Here we have to mention that according to official documents ${ }^{23}$, NBRB was expected to provide directed credits to the private sector upon the requests of state organizations during the whole period considered. The directed credits were assigned for such purposes as housing,

\footnotetext{
${ }^{23}$ See Annual reports of the National Bank of Belarus for 1998-2003.
} 
development of the agricultural sector, support of agricultural production, seeds purchasing, salary payments for the workers of state enterprises, state emergency, and trade. Therefore, the definition of private sector in Belarus might be vague and thus, should be extended to a broadly defined public sector.

Since the central bank with limited autonomy has been required to extend credit directly to enterprises or commercial banks upon a direct order from the government, the real scale of public sector transfers is much larger. However, the size of the public enterprise sector deficit cannot be measured precisely due to data limitations ${ }^{24}$ and estimating the size of quasi-fiscal operations of the central bank is beyond the scope of this study. The fiscal seigniorage and net investment of NBRB in non-governmental debt, which results from quasi-fiscal operations, is compared with the monetary seigniorage in Figure 2.

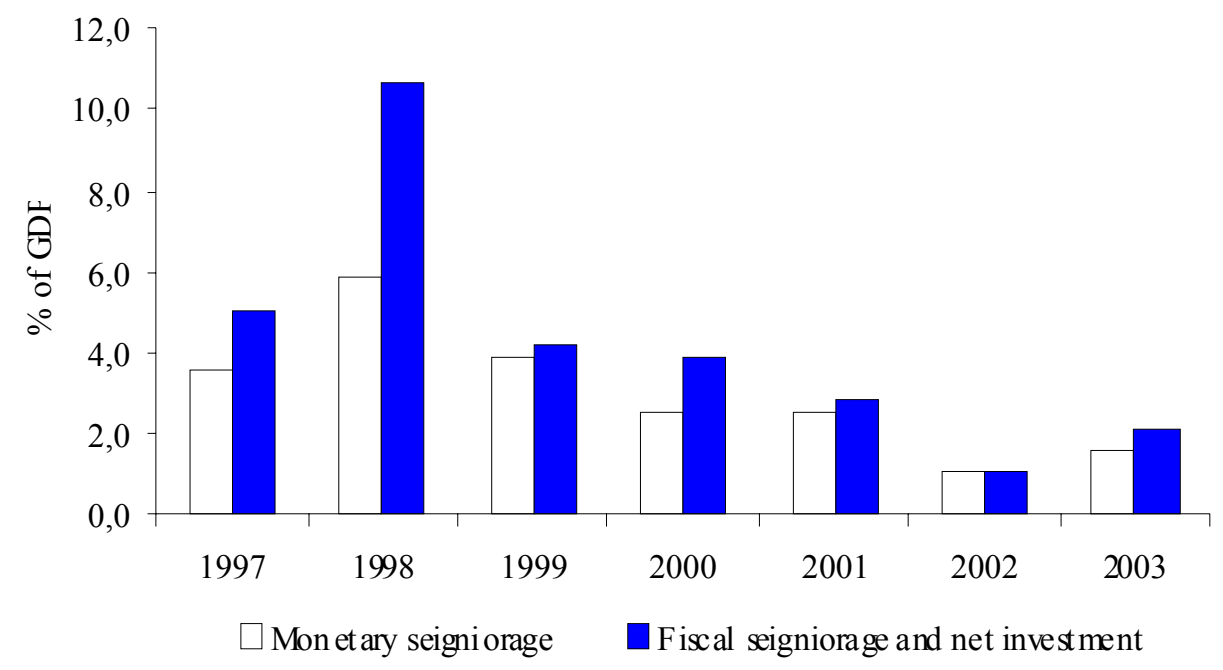

Figure 2. Belarus: monetary seigniorage versus fiscal seigniorage and net investment

\footnotetext{
${ }^{24}$ The resources are under the direct control of the presidential administration and publicly not available.
} 
Obviously, revenues from money creation were not enough, especially in 1998, to cover fiscal and quasi-fiscal (investment) expenditures of the NBRB, so it used its revenues earned on financial operations for covering the remaining part of such expenditures. Table 2 suggests that the revenues obtained from financial operations are about $0.6 \%$ of GDP during 1997-2003 on average in Belarus, so the central bank of Belarus must be using other sources of financing. According to the results presented in the Table 2 (see Appendix), when the difference between the monetary seigniorage and fiscal and quasifiscal investments of the central bank is very large, the amount of funds used for the accumulation of capital reserves and third party transfers (the $s^{O}$ item) is negative. These suggest that NBRB either decreased the size of its capital and reserves or used transfers from third parties for financing the fiscal seigniorage and its investments, or both. Presumably, it was converting the private or, more precisely, the non-governmental sector debt to the government sector.

\subsection{Kazakhstan}

Kazakhstan is the second (after Russia) largest country in CIS with a population of about $14.9 \mathrm{mln}$. and an area of $2728 \mathrm{sq} . \mathrm{km}$. The country is endowed with substantial mineral resources including oil, coal, and gas deposits and situated at the crossroads of Europe and Asia with an access to the Caspian Sea. A favorable position in terms of its natural resources endowment and geographical position among other Central Asian CIS countries leaves the country open for very promising prospects for economic development and contributes to the inflow of direct foreign investments. Since the beginning of economic transformation to a market economy, which started in 1991 by adopting the policies of price liberalization, privatization, and macroeconomic stabilization, the authorities of Kazakhstan achieved significant economic improvement. The economy overcame deep stagnation at the beginning of the 1990s and met strong growth by the end of the decade (see Table 3 in Appendix 1). Since 2000 high growth, a steady budget, a stable exchange rate, and balance of payment improvement characterize the economy of Kazakhstan. $^{25}$ 
According to official sources, both external as well as internal factors contributed to a significant economic improvement in Kazakhstan. First of all, a general improvement of the economic situation in CIS overall, especially in Russia, prompted a demand from neighbor countries for the Kazakh exports. Moreover, an increase in the prices of petroleum, gas, and other mineral products at the world market stimulated growth in the Kazakh oil industry attracting foreign direct investments and expanding exports. In the mean time, the government policies have been focused on macroeconomic stabilization and a creating favorable climate for foreign and domestic investors. It promoted large capital investments, especially, in the oil and gas industries. However, as a part of the stabilization policies, the prices of products produced by industries-natural monopolists (e.g. transportation of electricity, oil, and railway tariffs) in Kazakhstan are regulated by the state. This inevitably causes the widening of an underground economy, the size of which increased from $32.2 \%$ of GDP to $42.2 \%$ of GDP on average between 1990-1993 and 2000-2001 (Schneider 2002).

The banking system of Kazakhstan consists of the central bank, the National Bank of Kazakhstan (further NBK), and about forty commercial banks, from which two are owned by the government. ${ }^{26}$ Banking operations are regulated by the constitution; the law "On the National Bank of the Republic of Kazakhstan"; the law "On Banks and Banking in the Republic of Kazakhstan"; presidential decrees; international treaties concluded by the country; and other legislative acts. The objectives, institutional status and independence of the central bank, are determined by the law "On the National Bank of the Republic of Kazakhstan". According to this law, the primary goal of the NBK is to maintain price stability through the traditional instruments of monetary policy, ensuring the stability of the payment system, and foreign exchange regulation and controls. NBK is accountable to the president of Kazakhstan.

Although legislation stipulates the main principles of central bank independence, there exists a channel that limits the independence of NBK in practice. In particular,

${ }^{25}$ The Government Decree on the Concept of Financial Sector Development of the Republic of Kazakhstan of July 28, 2003, No. 753, Astana, Kazakhstan (in Russian). 
legislation emphasizes that NBK should operate independently, should act as a bank, financial adviser, and agent of the government bodies, and the state and government agencies have no right to interfere in its operations. ${ }^{27}$ Furthermore, NBK should not provide the government with direct financing. ${ }^{28}$ However, the structure of NBK's management, which consists of two boards - a supervisory board, the highest administrative body, and the board of directors, attracts special attention. In particular, the supervisory body, which is responsible for authorizing legal acts drafted by the NBK on major policy directions as well as on the main operational activities, consists of nine members including representatives delegated by the president and the government. As a result, state bodies can directly influence the decision-making process of the NBK on both major policy and operational issues. Therefore, in comparison to the central bank of Belarus, the central bank of Kazakhstan has a higher degree of autonomy, but its decisionmaking process can be influenced by the government.

The allocation of seigniorage revenues indicates that the size of fiscal seigniorage obtained by the government of Kazakhstan directly from the central bank is small. As Table 2 (in Appendix) shows the highest level of fiscal seigniorage ( $0.3 \%$ of GDP) was collected in 1998 and the lowest (-6.6\% of GDP) - in 2001. We should note that in all years, except 1998, the values of the fiscal seigniorage in Kazakhstan were negative.

\footnotetext{
${ }^{26}$ See Annual Report of NBK for 2003.

${ }^{27}$ See the Law “On the National Bank of the Republic of Kazakhstan” No. 2155, March 30, 1995.

${ }^{28}$ The practice of extending direct credits to the government for financing the budget deficit was banned in 1998.
} 


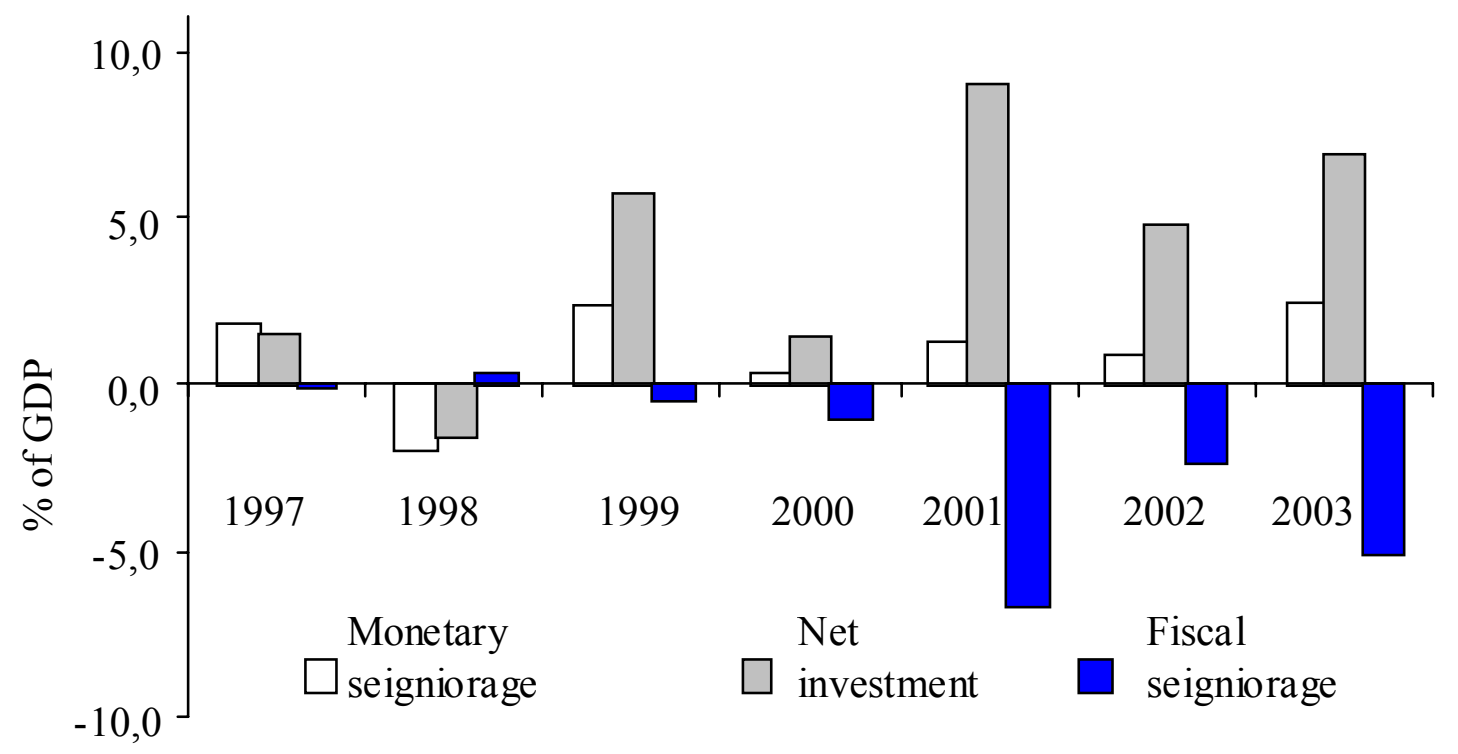

Figure 3. Kazakhstan: monetary seigniorage versus net investment and fiscal seigniorage

In other words, the NBK acted as a debtor rather than a creditor of the government. In this respect, the structure of the net investment component of NBK deserves special attention.

Generally, the activity of the NBK during the period considered in this study was highly responsive to the government policies since the supervisory board, which authorizes the major policy guidelines and operational activities of the NBK, includes the government as well as presidential representatives. In particular, the government priorities to strengthen investment activities in the economy and to support the business sector are reflected in the reporting system of the NBK. ${ }^{29}$ As Table 2 (see Appendix) illustrates, the net investments of the NBK are the largest portion of seigniorage usage during 1997-2003, reaching almost $3.9 \%$ of GDP, on average. The peak level of this component is indicated in 2001 (9.1\% of GDP) due to a large increase (by 1.8 times) in the foreign reserves of NBK. Since about a half of this inflow is from government funds, namely, oil-related funds and others state revenues (e.g., privatization receipts, rent payments for cosmodrome "Bajkonur"), fiscal seigniorage was the lowest (-6.6\% of GDP). In addition, 
the NBK extended large credits ${ }^{30}$ to the banking sector and various institutions both in domestic as well as foreign currencies to deal with one of the state priorities, to support the business sector of the country. It should be noted that major receivers of these directed credits were gold-mining companies and small and medium sized enterprises. So, the large net investments of the NBK have resulted from the inflows of government foreign reserves and credits extended to the real sector directly through the banking system.

Apart from foreign reserves held by the government, the NBK was also using government securities for its investment activities. Namely, it was acquiring the ownership of bonds issued by the Ministry of Finance of RK (MFRK) upon their placement in the primary market. In addition, it was issuing short-term notes, which are called "government securities issued by the NBK", ${ }^{11}$ both in domestic and foreign currencies with its privilege to specify all procedures and conditions on their selling and buying. Consequently, the NBK was transforming the government debt instrument into its own debt either through buying government securities with an ownership or issuing new securities on its own behalf and placing them in the primary market. This is another reason for a year by year reduction in the net claims of the NBK on the government and a negative sign of fiscal seigniorage.

\subsection{Russia}

Russia is the largest country in CIS with a vast territory $(17.075 \mathrm{mln}$. sq. $\mathrm{km})$ and a population of about $143.4 \mathrm{mln}$. The country endowed with substantial natural resources (e.g. oil, gas, coal, wood, and metals) has a large production, scientific, and technical potential for economic growth. The most important sectors of the economy are the oil and

\footnotetext{
${ }^{29}$ See, for example, Annual report of the NBK for 2000, 2001, and 2002.

${ }^{30}$ The volume of credits extended by commercial banks to the real sector increased by $77.3 \%$ in 2001 reaching almost $14.3 \%$ of GDP, of which $25 \%$ (or $3.6 \%$ of GDP) were directed credits to small- and medium- sized enterprises (see Annual report of NBK for 2001).
}

\footnotetext{
${ }^{31}$ See Article 36-2 of the Law "On the National Bank of the Republic of Kazakhstan" No. 2155, March 30, 1995.
} 
gas, industry, manufacturing, and construction. In the mean time, Russia is a country with large regional disparities; there are 89 federal subjects, ${ }^{32}$ and they differ radically one from another in key economic variables: income per capita, the levels of urbanization, the infrastructure of transport and communication, ethnic composition among others.

The performance of the Russian economy during its transition period was not considered successful compared to other Central European transition countries (e.g. Poland, the Czech Republic, and Hungary). Namely, economic policies were not as transparent as in Central European countries, and its economy was based on the export of natural resources and significant public sector expenses. In particular, the oil and gas sector provided major support to the export and fiscal sectors (Cukrowski 2004). In recent years, however, the economy has started to revive. As Table 3 (see Appendix 1) shows, the average annual growth rate of the economy is about $6 \%$ in the period $2000-2003$. Such speed is the result of both external and internal factors. According to official sources, a favorable foreign trade situation (e.g. an increase in oil prices, the depreciation of the US dollar against other major currencies) and the stabilization of the government's budgets played a key role.

However, despite economic growth and some progress in structural reforms (e.g. reduced tax burden on business, improvements in corporate governance reforms), price deregulation and the path of administrative reforms in recent years remain uncertain in Russia (see EBRD Transition Report 2004). Slow privatization, nationalization of key sectors, and low quality of public administration increase uncertainties about future economic performance. In particular, recent events connected with legal actions against the Yukos Oil Company started to worry foreign investors about property rights in Russia and slowed down the inflow of foreign direct investments. In addition, the weakness of state institutions, especially in public administration and the judiciary, and remaining price controls $^{33}$ have increased state interference and the country's shadow economy.

\footnotetext{
${ }^{32}$ The 89 federal subjects include 78 regions, which are oblasti, kraja, and republics, and 11 autonomous okrugs.

${ }^{33}$ Prices are the same for both households and producers in the electric-power industry, cargo transportation, and gas (Hanson 2003).
} 
Specifically, if the size of the black market was 27\% of GDP in 1990-1993, then it increased to $45.1 \%$ of GDP in 2000-2001, on average (Schneider 2002). The key challenges the Russian authorities face today are to increase the quality of public administration and the judiciary, to reduce state interference into the economy, to diversify the economy through promoting foreign investment and reducing dependence on commodity prices, and to achieve sound macroeconomic management.

The banking system of Russia includes the central bank, the Bank of Russia (BR) founded on July 13, 1990 and commercial banks. The activity, status, and powers of the BR are regulated by the Constitution of the Russian Federation, the Federal Law "On the Central Bank of the Russian Federation (Bank of Russia)", 34 and other federal laws. The main goals of the BR are to protect and to ensure the stability of the ruble, to develop and strengthen the banking system of Russia, and to guarantee the effectiveness of the payment system. Unlike Belarus and Kazakhstan where the governors of the central bank are accountable to the president, the chairman of the BR is accountable to the Parliament of Russia. The Parliament appoints and dismisses the chairman of the BR on requests made by the president of Russia and the board of directors of the BR. According to legislation, a key element of the legal status of BR is the principle of independence; the central bank should fulfill its functions independently from federal, regional, and local government bodies. However, as in the case of Kazakhstan the organization structure of BR's administration has a channel that might limit the actual independence of the Bank.

The management of the BR consists of the collegiate body and the board of directors. The collegiate body, which includes the chairman of the BR and officials from the president, government, parliament, and legislative organs, is responsible for reviewing reports of the BR and authorizing proposals for main policy guidelines. The board of directors, which consists of the chairman and twelve members appointed by the parliament at the recommendation of the chairman, deals with monetary policy in collaboration with

\footnotetext{
${ }^{34}$ The first version of the Law of RSFSR, the "Statute of the Central Bank of the RSFSR (Bank of Russia)", was approved in June 1991. In 1998 the banking legislation was amended. The last version of the Federal Law "On the Central Bank of the Russian Federation (Bank of Russia)" was passed by the State Duma on June 27, 2002.
} 
the government and decision-making on operational and managerial issues. Although legislation stipulates the segregation of duties between these two bodies ${ }^{35}$, the influence of state agencies on the decision making process in the BR is not excluded since all major policy and operational guidelines are the subject of approval by the highest body (e.g. the collegiate body).

Legislation prohibits the central bank to finance directly and indirectly the government budget through extending loans and buying government securities in the primary market. However, in some cases the federal budget law can overlook this rule. ${ }^{36}$ To demonstrate this, a comparison of the fiscal seigniorage and the monetary seigniorage of the BR during 1997-2003 is presented (Figure 4).

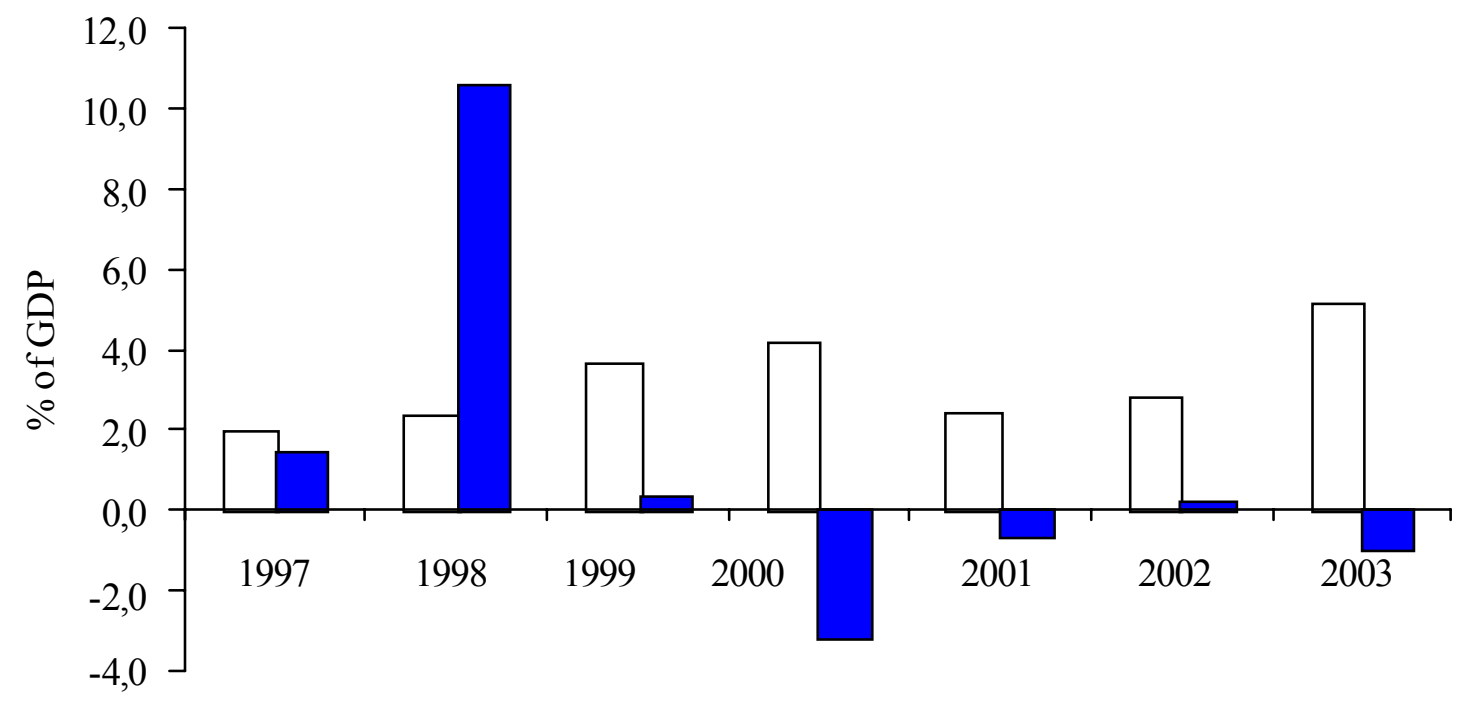

$\square$ Monetary seigniorage $\square$ Fiscal seigniorage

Figure 4. Russia: monetary and fiscal seigniorage

\footnotetext{
35 The members of the collegiate body except the chairman of the BR are prohibited from working in the Bank of Russia on a full-time basis and, consequently, being paid for their work in the body. The members of the board of directors, in their turn, are prohibited from participating in political parties, religious organization, the civil service, parliament, legislative and government bodies.
}

\footnotetext{
${ }^{36}$ The Article 22 of the Law on Bank of Russia stipulates: "The Bank of Russia shall not be entitled to extend loans to the Russian Federation Government to finance the federal budget deficit and buy securities at their primary placement, except for those cases stipulated by the federal budget law".
} 
As Figure 4 shows, during the first two years (e.g. 1997-1998) the BR was extensively financing the government budget and only with the beginning of macroeconomic stabilization, which started in 1999, has the amount of seigniorage to the government decreased from the central bank.

In 1997 the federal budget deficit reached 6.5\% of GDP and the primary source of funds for the federal budget came from the BR in the form of monetary seigniorage (1.9\%). In particular, the operations of the BR at security market with government bonds were the major source of fiscal transfers: buying the government bonds at the primary market contributed about $20 \%$ to budget transfers, and placing bonds in the secondary market contributed about $80 \%$. It should be noted, however, that the government debt on bonds $^{37}$ became the largest portion $(87.2 \%)$ of its total domestic debt in 1997. With the instability of world financial markets, which causes a decrease of foreign investments to emerging markets including Russia, the internal crisis factors in Russia (e.g. budget deficit, large government debts, depreciation of ruble) were intensified to such an extent that the government was no longer able to service its debt. On August 17, 1998 the Ministry of Finance of RF (MFRF) failed to meet its principal payments on government bonds and the government announced a default suspending all its payments on bonds. As a result, the BR stopped trading at both primary and secondary security markets. Government bonds ${ }^{38}$ issued before August 1998 were converted into eurobonds and restructured.

In the second half of 1998, the federal budget no longer received any revenues from government securities. As a result, the budget deficit, which reached $8.2 \%$ of GDP in 1998, was financed, primarily, from the foreign reserves of the BR, and the MFRF ran up a huge debt to the BR on operations with government bonds. At the end of the year the amount of MFRF's outstanding debt to the BR rose to 208.6 billion rubles (or $7.7 \%$ of GDP). The budget crisis (e.g. the government default, accumulation of a huge government

\footnotetext{
${ }^{37}$ Short term government bonds (GKO) and federal loan bonds (OFZ).

${ }^{38}$ The government securities such as short-term bonds (GKO) and federal loan bonds (OFZ) issued in July, 1998 were converted into eurobonds (see Annual report of the Bank of Russia for 1998).
} 
debt, and the lack of funds to repay it) increased the dependence of monetary policy on the fiscal situation; fiscal seigniorage of the BR reached its peak level (10.6\% of GDP) in 1998. It was financed by foreign reserves which caused a reduction of net investment by $3.8 \%$ of GDP; monetary seigniorage (2.3\% of GDP); third party transfers and reserves (1.9\% of GDP); and net interest revenues ( $0.1 \%$ of GDP). It should be noted that the remaining $2.9 \%$ of fiscal seigniorage was due to the book gains component. This is because the portfolio of the BR included debt instruments in foreign currency such as government loan bonds ${ }^{39}$ and direct credits the governments. Obviously, a sharp fall in the exchange rate against the USD (by 4 times) during the year increased the recorded value of these obligations in terms of the ruble, which amounted at the end of the year to about 169 bln. rubles (or $8.2 \mathrm{bln}$. USD). Thus, large depreciation of the ruble against the USD was reflected as a book gain component in fiscal seigniorage as well since a large portion of MFRF's outstanding debt to the BR was in foreign currency.

The size of the fiscal seigniorage declined from 10.6\% of GDP in 1998 to $0.3 \%$ of GDP in 1999 due to improvements in the field of government finance. The budget deficit in this period declined from $8.2 \%$ of GDP to $3.1 \%$ of GDP; however, difficulties in collecting taxes remained, and the MFRF continued to finance the budget deficit by monetary borrowing from the BR. The central bank was buying from the MFRF, federal bonds under non-market conditions (e.g. without interest payments and on a long-term basis with maturing dates in 2014-2023) ${ }^{40}$ and extending credits in foreign currency (4.5 bln. USD) to help the government service its foreign debt in time. Since the government began to restructure its debt incurred on securities issued earlier, a large part of federal loan bonds on the balance sheet of the RF was due 2018-2029 with either low interest (2\% p.a.) or no interest at all. At the end of year the debt of the MFRF to the BR amounted to 513.5 billion rubles $(7.4 \%$ of GDP) of which $33.9 \%$ (about 174.1 bln. rubles) were obligations in foreign currency.

\footnotetext{
${ }^{39}$ These obligations included the government loan bonds issued in foreign currency (OVGVZ); eurobonds issued in 1996-1998; and bonds issued by the MFRF for GKO restructuring.

${ }^{40}$ See the Annual Report of Bank of Russia for 1999.
} 
In 2000, the size of fiscal seigniorage transferred from the central bank to the government switched from a positive $(0.3 \%$ of GDP in 1999) to a negative number ($3.2 \%$ of GDP in 2000). This was caused by positive changes in the government finance, namely, a budget proficit (3.1\% of GDP) that allowed the MFRF to meet its debt obligations without extensive borrowing from the BR. The budget law, however, stipulated that the BR would provide the government with 30 billion rubles $(0.4 \%$ of GDP) through buying government securities at the primary market and with 1 billion USD through extending direct credit to the MFRF for foreign debt repayments. At the same time, the activation of investment activities in the economy and general banking stabilization allowed the central bank to increase its net investments to the private sector, which reached $7.6 \%$ of GDP by the end of 2000 .

In 2001 the MFRF and the BR completed the restructuring of government securities in the portfolio of the BR into federal loan bonds. The years 2002 and 2003 were of relatively high economic performance (the growth rate of GDP reached $4.3 \%$ and $7.3 \%$ and the budget surplus without grants reached $0.6 \%$ of GDP and $1.1 \%$ of GDP, respectively). This allowed the MFRF to pay its debt obligations both in ruble and dollar denominations to the BR. In 2003, the magnitude of fiscal seigniorage was small $(-0.1 \%$ of GDP) and negative indicating the fact the government restructured the government debt obligations into federal loan bonds without borrowing from the central bank.

\section{The welfare effect of monetary integration for Belarus, Kazakhstan, and Russia}

Planned monetary integration among the three countries considered in the paper will redistribute accumulated seigniorage wealth and will generate a significant welfare effect in each country. The pattern and size of this effect will be different across the countries. In this section, we look more closely at possible ways to distribute seigniorage wealth $^{41}$ in CMA and the potential gains or losses to be taken by each member country.

\footnotetext{
${ }^{41}$ Seigniorage wealth is determined as the difference of monetary base, which contains cash money circulated in the economy and central bank reserves held by the private banking system, and the portion the private bank reserves on which the central bank pays interests.
} 
Presumably, the distribution of seigniorage wealth created by CMA or, more precisely, the stake of seigniorage, which each country is going to receive after integration, will be determined by the initial endowment of a country in the equity capital of CEC. Therefore, the size of an equity share, which each participating country contributes to CEC, can be an important matter in negotiations towards integration. Below we consider three possible scenarios of determining equity shares and seigniorage division.

Scenario $I$. The equity share of a member country is proportional to its weight in the total level of seigniorage wealth created by all countries by the time the common currency area is established and the central banks are no longer responsible for their monetary policies as separate institutions. Thus, seigniorage wealth is determined based on two balance sheet variables which stand just before the day the central bank joins the common currency area: the amount of monetary base minus interest bearing central bank reserves held by private banks. The intuition behind this scenario is that the amount of seigniorage wealth, which is collected in the pre-integration period, already reflects the level of seigniorage desired by the government since it depends on the rate of monetary expansion chosen by policymakers.

Scenario II. The distribution of seigniorage revenues is similar to the case of seigniorage distribution in the EMU. In the case of the EMU the distribution of seigniorage created by the ECB or, more precisely, the stake of seigniorage, which each member-country receives, is determined by the initial endowment of a country in the equity capital of the ECB. The equity share ${ }^{42}$ of a member state in the ECB is determined as the average contribution of GDP (in constant prices) and population values to the total GDP and population in the euro-zone. Therefore, the size of the equity share, which each member-country of the CMA will contribute to the CEC, can be treated as an important matter of negotiations towards integration in the case of CIS countries.

Scenario III. This scenario is an adaptation of European rules to the conditions of CIS because given the fact that CIS countries have a large degree of state regulations and shadow economies, unlike EMU members, GDP in constant prices might not be relevant

\footnotetext{
${ }^{42}$ The distribution of seigniorage wealth generated by the EMU among its member states is regulated by the
} 
for this study. Therefore, we use GDP adjusted by Purchasing Power Parity (PPP) instead of GDP in constant prices and compare the real economic potential of CIS member countries. In order to calculate the equity shares of CIS member states in the CMA, the average GDP (adjusted by PPP) for the period 2000-2003 expressed in US dollar and population value for 2003 are used. We use the average value of GDP over the period 2000-2003 in order to smooth short-term shifts.

The share of interest bearing private bank assets (e.g. time deposits, security repurchase [REPO] operations), which are held in the central bank and accrue interests, in monetary base is quite low in all countries (less than $2-3 \%$ of monetary base on average during the analyzed period). In contrast, mandatory reserve requirements which force private banks to keep a part of their assets in the central bank are large. In particular, the required reserve-deposit ratio in all three countries significantly exceeds the threshold level (4\%) which distinguish, according to Sinn and Feist (1997), a highly regulated banking system ${ }^{43}$. This suggests in all three countries the liquidity of private banks for commercial financial operation is very limited.

However, preparations towards integration may involve some liberalization and development of the banking sector which will lead to an increase in the portion of interest bearing reserves in monetary base and in the liquidity of commercial banks. This implies that the share of each country in the total seigniorage wealth will change from the current state, and the pattern of this change will depend on the degree and speed of banking liberalization. If the banking sectors in three countries are liberalized with different degrees and speeds, this will change the composition of the monetary base in terms of interest bearing and non-interest bearing private bank reserves and will eventually alter the share of each country in total seigniorage wealth. In this respect, a simplified rule of seigniorage distribution described in Scenario 1, which is based on seigniorage wealth created by the three countries in an environment of a highly regulated banking system, will not be preferred. So most probably, the basic scheme of integration among CIS

Protocol on the "Statue of the European System of Central Banks and the ECB" (see articles 32.2 and 32.5).

${ }^{43}$ In more liberal banking systems the reserve-deposit ratio usually does not exceed 2\% (Feist and Sinn 1997). 
countries will look like the EMU version of integration since the main policy strategies towards CEA and CMA are very similar to EU and EMU guidelines ${ }^{44}$.

The welfare effect of CMA under Scenario 2 is determined as the difference of the equity and seigniorage weights of its member country multiplied by the total amount of seigniorage wealth accumulated by all countries by the end of 2003. Consequently, the size of countries in terms of population and GDP, which determine the size of equity share, on the one hand, and the amount of seigniorage wealth generated in the preintegration period, on the other, would be important elements of the welfare effect. The equity shares of participating countries calculated according to our three scenarios are presented in Table 1.

Table 1. Equity shares of CIS member states in the CMA

\begin{tabular}{|c|c|c|c|c|c|}
\hline Scenario 1 & $\begin{array}{l}\text { Seigniorage } \\
\text { wealth, as of end } \\
\text { of } 2003 \\
\text { (mln. national } \\
\text { currencies) }\end{array}$ & $\begin{array}{l}\text { Exchange rates: } \\
\text { as of end of } 2003 \\
\text { BYB/USD, } \\
\text { KZT/USD, and } \\
\text { RUR/USD }\end{array}$ & $\begin{array}{l}\text { Seigniorage } \\
\text { wealth, as of } \\
\text { end of } 2003 \\
\text { (mln. USD) }\end{array}$ & $\begin{array}{l}\text { Share in } \\
\text { seigniorage } \\
\text { wealth } \\
(\%)\end{array}$ & $\begin{array}{l}\text { Equity share } \\
\text { in CMA }(\%)\end{array}$ \\
\hline Belarus & 1629204 & 2156.00 & 756 & 1.18 & 1.18 \\
\hline Kazakhstan & 308144 & 144.22 & 2137 & 3.34 & 3.34 \\
\hline Russia & 1796900 & 29.45 & 61006 & 95.47 & 95.47 \\
\hline Total & $\#$ & $\#$ & 63898 & 100.00 & 100.00 \\
\hline Scenario 2 & $\begin{array}{l}\text { Population } \\
\text { (mln. people) }\end{array}$ & $\begin{array}{l}\text { GDP } \\
\text { (constant 1995), } \\
\text { average in 2000-2003 } \\
\text { (bln. USD) }\end{array}$ & $\begin{array}{l}\text { Population } \\
\text { (share, \%) }\end{array}$ & $\begin{array}{l}\text { GDP } \\
\text { (share, \%) }\end{array}$ & $\begin{array}{l}\text { Equity share } \\
\text { in CMA (\%) }\end{array}$ \\
\hline Belarus & 9.88 & 14.34 & 5.87 & 3.84 & 4.86 \\
\hline Kazakhstan & 14.91 & 24.00 & 8.86 & 6.43 & 7.64 \\
\hline Russia & 143.43 & 335.14 & 85.26 & 89.73 & 87.50 \\
\hline Total & 168.22 & 373.49 & 100.00 & 100.00 & 100.00 \\
\hline Scenario 3 & $\begin{array}{l}\text { Population } \\
\text { (mln. people) }\end{array}$ & $\begin{array}{l}\text { GDP by PPP } \\
\text { (constant 1995), } \\
\text { average in 2000-2003 } \\
\text { (bln. USD) }\end{array}$ & $\begin{array}{l}\text { Population } \\
\text { (share, \%) }\end{array}$ & $\begin{array}{l}\text { GDP by PPP } \\
(\text { share }, \%)\end{array}$ & $\begin{array}{l}\text { Equity share } \\
\text { in CMA }(\%)\end{array}$ \\
\hline Belarus & 9.88 & 46.23 & 5.87 & 4.11 & 4.99 \\
\hline Kazakhstan & 14.91 & 69.86 & 8.86 & 6.21 & 7.54 \\
\hline Russia & 143.43 & 1008.37 & 85.26 & 89.68 & 87.47 \\
\hline Total & 168.22 & 1124.46 & 100.00 & 100.00 & 100.00 \\
\hline
\end{tabular}

Sources: National Statistic Committees of Belarus, Kazakhstan, and Russia; Annual reports of the NBRB, the NBK, and the BR

${ }^{44}$ See Concept on the Establishment of the Common Economic Area of September 19, 2003 (draft in Russian). 
As Table 1 demonstrates under Scenario 1, when countries are assumed to contribute to the common emitting center the accumulated seigniorage wealth, Russia has the largest equity share (95.5\%) and Belarus the smallest (1.2\%).

In the Scenario 2, under which the equity shares are calculated similar to EMU rules, the share of Russia is somewhat smaller (87.5\%), while the shares of Belarus and Kazakhstan increase significantly from $1.1 \%$ to $4.9 \%$ and $3.3 \%$ to $7.6 \%$, respectively. This is because both population and GDP shares of Belarus and Kazakhstan, unlike those of Russia, are much larger than their corresponding shares in the total seigniorage wealth accumulated by all countries. Under Scenario 3, where GDP adjusted by PPP is used, the equity share of Russia is almost the same as in the previous case $(87.5 \%)$. However, a small increase in the weight of Belarus by $0.1 \%$ contributes to an increase in its welfare gains by 86.4 million USD. Correspondingly, a decrease in the weight of Kazakhstan (by $0.1 \%$ ) leads to a decrease in its welfare gain by $68.4 \mathrm{mln}$. USD.

Based on estimated values of the equity share, the pattern and scale of welfare effect in each participating country is presented in Table 2.

Table 2. Welfare effect of monetary integration

\begin{tabular}{|l|r|r|r|r|r|}
\hline \hline & $\begin{array}{l}\text { Equity } \\
\text { share in } \\
\text { CMA (\%) }\end{array}$ & $\begin{array}{l}\text { Seigniorage } \\
\text { wealth in 2003 } \\
\text { (mln. USD) }\end{array}$ & $\begin{array}{l}\text { Share in } \\
\text { seigniorage } \\
\text { wealth (\%) }\end{array}$ & $\begin{array}{l}\text { Total gain } \\
\text { (mln. USD) }\end{array}$ & $\begin{array}{l}\text { Gain per } \\
\text { capita } \\
\text { (USD) }\end{array}$ \\
\hline Belarus & 4.86 & 755.66 & 1.18 & 2347.72 & 237.62 \\
\hline Kazakhstan & 7.64 & 2136.62 & 3.34 & 2748.04 & 184.31 \\
\hline Russia & 87.50 & 61005.96 & 95.47 & -5095.76 & -35.53 \\
\hline Total & 100.00 & 63898.24 & 100.00 & 0.00 & \# \\
\hline \multicolumn{7}{|c|}{ Scenario 2 } \\
\hline Belarus & 6.06 & 755.66 & 1.18 & 2434.16 & 246.37 \\
\hline Kazakhstan & 8.59 & 2136.62 & 3.34 & 2679.67 & 179.72 \\
\hline Russia & 85.35 & 61005.96 & 95.47 & -5113.83 & -35.65 \\
\hline Total & 100.00 & 63898.24 & 100.00 & 0.00 & $\#$ \\
\hline
\end{tabular}

Sources: Annual reports of the NBRB, the NBK, the BR, and the author's calculations

According to the results, which are based on a comparison of the equity shares of participating countries with their corresponding seigniorage shares in CMA, Russia would 
lose in all considered scenarios, while Kazakhstan and Belarus would gain. As Table 2 reveals, the loss to be taken by Russia is quite large with an estimate of about 5 bln. USD in both alternative scenarios. Kazakhstan and Belarus, on the contrary, would enjoy a big welfare gain. In particular, the sizes of a welfare gain per capita to be taken by Belarus and Kazakhstan are 237.6 USD and 184.3 USD under Scenario 2 and 246.4 USD and 179.7 USD under Scenario 3, respectively.

One of the reasons for welfare transfers among countries within a monetary union is related to the existence of differences in banking regulations and the level of seigniorage wealth collected during the pre-integration period (Sinn and Feist 1997, 2000). Specifically, a country with a highly regulated banking system and with strict requirements to private banks usually loose when it integrates with a country where private banks have more flexibility to manage their liquidity. This is because in the environment of strict regulations the amount of reserves, which is required by the central bank, is high relative to the opposite case. As a result, the share of a country in the total seigniorage wealth of integrating countries is significantly larger than its equity share in

the common emitting center, and the welfare effect is always negative. In contrast, a country with a more liberal banking system usually gains since its monetary base is not significantly large compared to countries with a more regulated banking system.

Large welfare transfers among countries can also stem from differences in national wealth (Cukrowski and Fischer 2002). This is because the population share of poorer countries in a monetary union are much larger than their respective GDP shares; consequently, their larger capital shares relative to the share of seigniorage wealth in a common pool will allow them to receive a larger portion of seigniorage. Along with the size of countries in terms of population and GDP and differences among countries in banking regulations, welfare transfer between economically large and small countries takes place also because of political reasons (Casella 1992).

\section{Conclusion}

In light of a recent trend in the CIS towards monetary integration among Belarus, Kazakhstan, and Russia, the present paper analyzis the importance of seigniorage revenues 
in these countries during 1997-2003, possible ways to distribute seigniorage in the CMA, and the expected welfare effect of monetary integration. The concept of total gross seigniorage, which allows one to analyze seigniorage in the broadest possible sense as the sum of all revenue flows from the central bank to the government, is applied. Namely, we explored and compared across three countries the process of generating and allocating seigniorage (e.g. its four main sources and uses), taking into account the legal, institutional, and operational arrangements of their central banks and giving special attention to the magnitude of fiscal seigniorage transferred to the government. Based on three alternative scenarios of seigniorage division among the member countries of the CMA, the distribution of gain or loss across countries is estimated.

Empirical results reveal that the manner of collecting seigniorage revenues by the central banks is similar across the countries (monetary expansion is a main source of seigniorage revenues and revenues obtained on interest earnings and financial operations are low). The structure of seigniorage in terms of its distribution is a bit different both across countries and time. Before 1999, the monetary authorities of Belarus and Russia used a large portion of their seigniorage revenues for financing the state budget while the central bank of Kazakhstan used it for reserve funds. From 1999 onwards, the magnitude of fiscal seigniorage shows a declining tendency (especially in Russia). The comparison of fiscal seigniorage across countries after 1999 suggests that the government of Belarus, which gives its central bank very limited autonomy, more strongly relies on seigniorage revenues to finance its state budget than in Kazakhstan and Russia. In these countries, the situation is different since those governments obtain substantial revenues from the oil sectors and central banks have more political and economic independence.

The analysis of a welfare impact of monetary integration suggests that Russia would shoulder a welfare loss while Kazakhstan and Belarus would gain substantially. This is because the share of Russia in the seigniorage wealth of all countries is much larger than its equity share in the capital of CEC. This finding is consistent with earlier findings (Cukrowski and Fischer 2002) that show a large disparity in the economic size translates to a transfer of seigniorage wealth from large to small countries (the smaller the country is in terms of GDP and population, the larger the amount of welfare gain). 
Welfare transfer among three countries can be interpreted in the context of distribution in power over common decisions in monetary union (Casella 1992), which is left for further research. Results presented in this paper should be useful in negotiations among the member states towards integration and in the determining rules regulating the distribution of seigniorage wealth in the common area. 


\section{Appendix: Tables}

Table 1. Balance sheets and financial statements of the central banks of Belarus, Kazakhstan, and Russia

\begin{tabular}{|c|c|c|c|c|c|c|c|}
\hline \multicolumn{8}{|c|}{ Belarus } \\
\hline $\begin{array}{l}\text { Balance sheet (mln. rubles, } \\
\text { as of end of the period) }\end{array}$ & 1997 & 1998 & 1999 & 2000 & 2001 & 2002 & 2003 \\
\hline \multicolumn{8}{|l|}{ Assets } \\
\hline Foreign assets & 12333 & 76465 & 98355 & 423560 & 706179 & 1439900 & 1788900 \\
\hline \multicolumn{8}{|l|}{ Domestic assets, claims on: } \\
\hline -government & 14448 & 54930 & 153755 & 302799 & 504345 & 190416 & 643263 \\
\hline -resident cred & 17046 & 51229 & 60226 & 107082 & 180557 & 255447 & 332130 \\
\hline Other assets & 172 & 365 & 2085 & 7547 & 12577 & 17019 & 23521 \\
\hline Total assets & 43999 & 182989 & 314421 & 840988 & 1403658 & 1902782 & 2787814 \\
\hline \multicolumn{8}{|l|}{\begin{tabular}{|l|} 
Liabilities \\
\end{tabular}} \\
\hline Foreign liabilities & 9791 & 70720 & 81722 & 245979 & 344175 & 593814 & 650394 \\
\hline \multicolumn{8}{|l|}{ Domestic liabilities } \\
\hline Bankn & 12300 & 27074 & 86852 & 238796 & 512211 & 650020 & 926438 \\
\hline Govern & 2010 & 6490 & 15072 & 41741 & 35100 & 22569 & 126677 \\
\hline $\begin{array}{l}\text { Funds of resident credit } \\
\text { Institutions }\end{array}$ & 12915 & 39227 & 97828 & 175539 & 332744 & 466270 & 760352 \\
\hline Other & 23 & 81 & 139 & 306 & 757 & 2 & 186 \\
\hline Total liabilities & 37038 & 143591 & 281614 & 702361 & 1224987 & 1732675 & 2464047 \\
\hline Capital and reserves & 3694 & 5968 & 24895 & 129194 & 185695 & 311865 & 474978 \\
\hline Other items(net) & 3266 & 33430 & 7912 & 9433 & -7024 & -141758 & -151211 \\
\hline The sum of liabilities & 43999 & 182989 & 314421 & 840988 & 1403658 & 1902782 & 2787814 \\
\hline $\begin{array}{l}\text { Financial report } \\
\text { (mln. rubles, flow per year) }\end{array}$ & 1997 & 1998 & 1999 & 2000 & 2001 & 2002 & 2003 \\
\hline Interest incomes & 1773 & 4059 & 13919 & 30496 & 82124 & 66314 & 93819 \\
\hline Interest payments & -1850 & -3812 & -8132 & -13900 & -18648 & -29763 & -57651 \\
\hline Net interest incomes & -77 & 246 & 5787 & 16596 & 63476 & 36551 & 36167 \\
\hline Other net incomes & 4149 & 4458 & 35914 & 28605 & 22390 & 63943 & 82718 \\
\hline $\begin{array}{l}\text { Income before provision for } \\
\text { losses }\end{array}$ & 4072 & 4704 & 41701 & 45201 & 85866 & 104921 & 119230 \\
\hline Provisions for possible losses & -970 & -1892 & -3378 & -8399 & -13042 & -4978 & $-864,2$ \\
\hline $\begin{array}{l}\text { Operational income (after } \\
\text { using provisions for losses) }\end{array}$ & 3103 & 2812 & 38323 & 36801 & 72823 & 99943 & 118366 \\
\hline \multicolumn{8}{|l|}{$\begin{array}{l}\text { Operational expenses, } \\
\text { including: }\end{array}$} \\
\hline staff expenses; & -321 & -661 & -2578 & -8000 & -17139 & -25615 & -31685 \\
\hline depreciation; & -48 & -97 & -229 & -1627 & -4887 & -13986 & -15036 \\
\hline banknotes and coin issue; & -1 & -110 & -1794 & -1695 & -1447 & -1929 & -3777 \\
\hline Administrative expenses & -237 & -488 & -2888 & -6728 & -24235 & -29760 & -34229 \\
\hline Transfers to the budget & -1331 & -1206 & -15727 & -16291 & -12558 & -13977 & -16819 \\
\hline $\begin{array}{l}\text { Net profit after transfer } \\
\text { payments }\end{array}$ & 1165 & 250 & 15107 & 2460 & 12558 & 13977 & 16819 \\
\hline
\end{tabular}




\begin{tabular}{|c|c|c|c|c|c|c|c|}
\hline \multicolumn{8}{|c|}{ Kazakhstan } \\
\hline $\begin{array}{l}\text { Balance sheet } \\
\text { (mln. tenges, } \\
\text { as of end of the period) } \\
\end{array}$ & 1997 & 1998 & 1999 & 2000 & 2001 & 2002 & 2003 \\
\hline \multicolumn{8}{|l|}{ Assets } \\
\hline \begin{tabular}{|l|} 
Foreign assets \\
\end{tabular} & 172971 & 164663 & 276713 & 302950 & 565816 & 788081 & 1241530 \\
\hline \multicolumn{8}{|l|}{ Domestic assets, claims on: } \\
\hline - government & 77078 & 87931 & 109304 & 41568 & 19133 & 19230 & 2946 \\
\hline - resident credit & 8248 & 2084 & 4634 & 2774 & 1810 & 3758 & 3150 \\
\hline Other assets & 620 & 7277 & 12657 & 2146 & 3586 & 4060 & 6349 \\
\hline Total assets & 258918 & 261954 & 403308 & 349438 & 590345 & 815129 & 1253975 \\
\hline \multicolumn{8}{|c|}{ 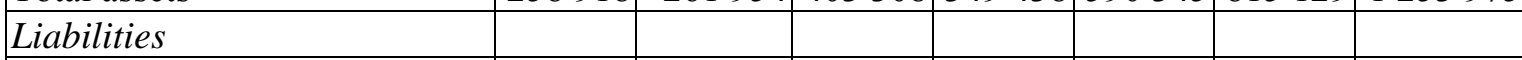 } \\
\hline Foreign liabilities & 42409 & 56354 & 66097 & 286 & 346 & 390 & 6543 \\
\hline \multicolumn{8}{|l|}{ Domestic liabilities } \\
\hline $\begin{array}{l}\text { Banknotes and coins in } \\
\text { circulation }\end{array}$ & 92796 & 68728 & 103486 & 106428 & 131174 & 161701 & 238730 \\
\hline Government funds & 53647 & 59766 & 93899 & 57507 & 256768 & 356425 & 570924 \\
\hline $\begin{array}{l}\text { Funds of resident credit } \\
\text { institutions }\end{array}$ & 22593 & 12700 & 23263 & 27988 & 44377 & 46470 & 78142 \\
\hline Other liabilities & 6872 & 12093 & 7313 & 49882 & 18547 & 65304 & 205763 \\
\hline Total liabil & 218318 & 209641 & 294058 & 242090 & 451212 & 630290 & 1100102 \\
\hline Capital and reserves & 52611 & 63480 & 121957 & 118963 & 134371 & 179834 & 167299 \\
\hline Other items (net) & -12012 & -11167 & -12707 & -11615 & 4761 & 5005 & -13424 \\
\hline The sum of liabilities & 270929 & 273121 & 416015 & 361053 & 585583 & 815129 & 1253978 \\
\hline \begin{tabular}{|l|} 
Financial report \\
(mln. tenges, flow per year)
\end{tabular} & 1997 & 1998 & 1999 & 2000 & 2001 & 2002 & 2003 \\
\hline Interest incomes & 5628 & 5654 & 7813 & 17126 & 29373 & 21446 & 15538 \\
\hline Interest payments & -3701 & -3058 & -4555 & -4775 & -11453 & -6448 & -12597 \\
\hline Net in & 1927 & 2595 & 3257 & 12351 & 17920 & 14998 & 2941 \\
\hline Other net incomes & 3159 & 3107 & 8582 & 17165 & 16706 & 47578 & -1742 \\
\hline $\begin{array}{l}\text { Income before provision for } \\
\text { losses }\end{array}$ & 5087 & 5702 & 11839 & 29516 & 34626 & 62576 & 1199 \\
\hline Provisions for possible losses & -185 & -1294 & -3805 & -16010 & -9761 & -5834 & 12606 \\
\hline $\begin{array}{l}\text { Operational income } \\
\text { (after using provisions for } \\
\text { losses) }\end{array}$ & 4902 & 4409 & 8034 & 13507 & 24865 & 56741 & 13805 \\
\hline \multicolumn{8}{|l|}{ Operational expenses: } \\
\hline staff expenses; & -719 & -977 & -1144 & -2086 & -2766 & -2878 & -3221 \\
\hline depreciation; & -456 & -686 & -425 & -1414 & -664 & -1028 & -1104 \\
\hline banknotes and c & -602 & -229 & -654 & -786 & -1118 & -1085 & -2736 \\
\hline $\begin{array}{l}\text { other administrative } \\
\text { expenses }\end{array}$ & -2719 & -2316 & -2671 & -2404 & -1506 & -1557 & -1713 \\
\hline Transfers to the budget & -406 & -109 & -3202 & -5795 & -6234 & -10519 & -5691 \\
\hline Net profit after transfers & 0 & 91 & -63 & 1022 & 12576 & 39674 & -660 \\
\hline
\end{tabular}




\begin{tabular}{|c|c|c|c|c|c|c|c|}
\hline & & & Russia & & & & \\
\hline $\begin{array}{l}\text { Balance sheet } \\
\text { (mln. rubles, } \\
\text { as of end of the period) }\end{array}$ & 1997 & 1998 & 1999 & 2000 & 2001 & 2002 & 2003 \\
\hline Assets & & & & & & & \\
\hline Foreign assets & 123344 & 86324 & 383899 & 842445 & 1163850 & 1615680 & 2391100 \\
\hline Domestic assets & & & & & & & \\
\hline - government & 226049 & 525374 & 572030 & 504702 & 488102 & 551547 & 477640 \\
\hline - resident credit is & \begin{tabular}{|l|}
11119 \\
\end{tabular} & 76438 & 202944 & 206501 & 250187 & 223991 & 198742 \\
\hline Other assets & 327 & 562 & 430 & 367 & 248 & 2239 & 2319 \\
\hline Total assets & 360839 & 888698 & 1159303 & 1554015 & 1902387 & 2393457 & 3069801 \\
\hline Liabil & & & & & & & \\
\hline Foreign liabilities & 9744 & 401551 & 424201 & 331056 & 287413 & 233030 & 220638 \\
\hline Don & & & & & & & \\
\hline $\begin{array}{l}\text { Banl } \\
\text { circt }\end{array}$ & 130474 & 187679 & 266146 & 418871 & 583839 & 763245 & $\begin{array}{|ll|}1 & 147040\end{array}$ \\
\hline Gove & 21313 & 41863 & 75872 & 240488 & 294914 & 357878 & 446001 \\
\hline $\begin{array}{l}\text { esident credit } \\
\mathrm{S}\end{array}$ & 79976 & 75996 & 173597 & 320887 & 367455 & 500485 & 800670 \\
\hline Othe & 240 & 1828 & 1575 & 7 & 2 & 29 & 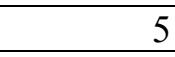 \\
\hline Total 1 & 311747 & 708917 & 941391 & 1311309 & 1533623 & 1854667 & 2614354 \\
\hline Capit & 69552 & 118113 & 151844 & 166048 & 242312 & 364731 & 298727 \\
\hline Other ite & -20460 & 61668 & 66068 & 76658 & 126452 & 174059 & 156720 \\
\hline The sum of liabilities & 360839 & 888698 & 1159303 & 1554015 & 1902387 & 2393457 & 3069801 \\
\hline $\begin{array}{l}\text { Financial report } \\
\text { (mln. rubles, flow per year) }\end{array}$ & 1997 & 1998 & 1999 & 2000 & 2001 & 2002 & 2003 \\
\hline Interest & 2056 & 4072 & 4399 & 27848 & 36549 & 46914 & 44862 \\
\hline Intere & -1089 & -1774 & -7489 & -10337 & -8124 & -8189 & -3083 \\
\hline Net interest incomes & 967 & 2298 & -3090 & 17511 & 28425 & 38725 & 41779 \\
\hline $\begin{array}{l}\text { Other net } \\
\text { financial o }\end{array}$ & 14968 & 3324 & 48839 & 46508 & 59905 & 47914 & 64143 \\
\hline $\begin{array}{l}\text { Income before provision for } \\
\text { losses }\end{array}$ & 15935 & 5622 & 45749 & 64019 & 88330 & 86639 & 105922 \\
\hline Provisions for possible losse & 2966 & -12537 & -19486 & -31497 & -26367 & 0 & 0 \\
\hline $\begin{array}{l}\text { Operational income (after } \\
\text { using provisions for losses) }\end{array}$ & 12969 & -6915 & 26263 & 32522 & 61963 & 86639 & 105922 \\
\hline Operational expenses: & & & & & & & \\
\hline staffe & -7463 & -8601 & -11113 & -13727 & -21055 & -28870 & -29196 \\
\hline banknotes and coin issu & -1098 & -1930 & -1550 & -2207 & -2597 & -2767 & -3139 \\
\hline $\begin{array}{l}\text { other administrative } \\
\text { expenses; }\end{array}$ & -1621 & -10383 & -12415 & -12409 & -20228 & -22628 & -18859 \\
\hline Transfers to the budget & -1985 & 0 & -593 & -2090 & -9042 & -24923 & -29806 \\
\hline Net profit after transt & 802 & $\begin{array}{lll}-27 & 829 \\
\end{array}$ & 592 & 2089 & 9041 & 7451 & 24922 \\
\hline
\end{tabular}

Sources: IFS (2004), annual reports of the NBRB, the NBK, and the BR 
Table 2. Sources and uses of seigniorage in Belarus, Kazakhstan, and Russia (\% of GDP)

\begin{tabular}{|c|c|c|c|c|c|c|c|}
\hline & 1997 & 1998 & 1999 & 2000 & 2001 & 2002 & 2003 \\
\hline \multicolumn{8}{|c|}{ Total seigniorage $\left(s_{t}\right)$} \\
\hline Belarus & 4.68 & 8.48 & 5.26 & 3.41 & 3.29 & 2.82 & 2.21 \\
\hline Kazakhstan & 2.39 & 2.63 & 6.61 & 2.17 & 9.07 & 5.21 & 7.81 \\
\hline Russia & 2.59 & 9.80 & 4.27 & 7.70 & 4.22 & 4.02 & 6.93 \\
\hline \multicolumn{8}{|c|}{ The sources of seigniorage } \\
\hline \multicolumn{8}{|c|}{ Monetary seigniorage $\left(s^{M}\right)$} \\
\hline Belarus & 3.56 & 5.85 & 3.91 & 2.51 & 2.51 & 1.04 & 1.59 \\
\hline Kazakhstan & 1.86 & $-1.96^{*}$ & 2.25 & 0.29 & 1.27 & 0.86 & 2.44 \\
\hline Russia & 1.94 & 2.25 & 3.67 & 4.10 & 2.43 & 2.77 & 5.14 \\
\hline \multicolumn{8}{|c|}{ Net interest revenues $\left(s^{I}\right)$} \\
\hline Belarus & $-0.02 *$ & 0.04 & 0.19 & 0.18 & 0.37 & 0.14 & 0.10 \\
\hline Kazakhstan & 0.12 & 0.15 & 0.16 & 0.48 & 0.55 & 0.40 & 0.07 \\
\hline Russia & 0.04 & 0.09 & $-0.06^{*}$ & 0.24 & 0.32 & 0.36 & 0.31 \\
\hline \multicolumn{8}{|c|}{ Net revenues from $\mathrm{CB}$ operations $\left(s^{O P}\right)$} \\
\hline Belarus & 0.87 & 0.37 & 1.08 & 0.22 & 0.05 & 0.24 & 0.23 \\
\hline Kazakhstan & 0.18 & 0.10 & 0.24 & 0.04 & 0.21 & 1.11 & 0.24 \\
\hline Russia & 0.51 & $-0.35 *$ & 0.61 & 0.21 & 0.37 & 0.44 & 0.48 \\
\hline \multicolumn{8}{|l|}{ Book gains $\left(s^{R I}\right)$} \\
\hline Belarus & 0.25 & 2.23 & 0.09 & 0.49 & 0.35 & 0.30 & 0.29 \\
\hline Kazakhstan & 0.15 & 0.82 & 3.49 & 0.37 & 0.41 & 0.49 & $-1.32 *$ \\
\hline Russia & 0.10 & 4.09 & $-0.70^{*}$ & $-0.02 *$ & 0.41 & 0.45 & $-0.76^{*}$ \\
\hline \multicolumn{8}{|c|}{ The uses of seigniorage } \\
\hline \multicolumn{8}{|c|}{ The costs of printing notes and maintaining operations $\left(s^{C}\right)$} \\
\hline Belarus & 0.17 & 0.19 & 0.25 & 0.20 & 0.28 & 0.27 & 0.24 \\
\hline Kazakhstan & 0.27 & 0.24 & 0.24 & 0.26 & 0.19 & 0.17 & 0.20 \\
\hline Russia & 0.43 & 0.80 & 0.52 & 0.39 & 0.49 & 0.50 & 0.38 \\
\hline \multicolumn{8}{|c|}{ Net investment $\left(s^{N I}\right)$} \\
\hline Belarus & 3.26 & 5.34 & 0.71 & 2.33 & 1.53 & 2.16 & 1.04 \\
\hline Kazakhstan & 1.55 & $-1.56^{* *}$ & 5.71 & 1.43 & 9.06 & 4.71 & 6.93 \\
\hline Russia & 0.47 & $-3.38 * *$ & 4.19 & 7.62 & 4.63 & 4.34 & 5.73 \\
\hline \multicolumn{8}{|c|}{ Reserves, capital and transfers from(-)/to $(+)$ parties $\left(s^{O}\right)$} \\
\hline Belarus & $-0.48^{* *}$ & $-2.36^{* *}$ & 0.80 & $-0.64 * *$ & 0.19 & 0.39 & $-0.09 * *$ \\
\hline Kazakhstan & 0.58 & 0.15 & 0.66 & 0.48 & $-0.18^{* *}$ & 0.33 & $-0.64 * *$ \\
\hline Russia & 0.22 & $-1.95 * *$ & $-1.47 * *$ & $-0.33 * *$ & $-0.90 * *$ & $-1.05 * *$ & 0.05 \\
\hline \multicolumn{8}{|c|}{ Fiscal seigniorage $\left(s^{G}\right)$} \\
\hline Belarus & 1.71 & 5.30 & 3.50 & 1.52 & 1.29 & $-1.10 * *$ & 1.02 \\
\hline Kazakhstan & $-0.09 * *$ & 0.28 & $-0.47 * *$ & $-0.98 * *$ & $-6.63 * *$ & $-2.36^{* *}$ & $-5.06^{* *}$ \\
\hline Russia & 1.47 & 10.60 & 0.27 & $-3.15^{* *}$ & $-0.69 * *$ & 0.23 & $-0.99 * *$ \\
\hline
\end{tabular}

*) Negative values relate to the uses of seigniorage

**) Negative values relate to the sources of seigniorage

Source: IFS (2004), annual reports of the NBRB, the NBK, and the BR, and author's calculations 
Table 3. Macroeconomic indicators in Belarus, Kazakhstan, and Russia during 1997-2003

\begin{tabular}{|c|c|c|c|c|c|c|c|}
\hline & 1997 & 1998 & 1999 & 2000 & 2001 & 2002 & 2003 \\
\hline \multicolumn{8}{|c|}{ Belarus } \\
\hline GDP growth (annual \%) & 11.40 & 8.40 & 3.40 & 5.80 & 4.70 & 5.00 & 6.75 \\
\hline Inflation (annual \%) & 63.92 & 72.89 & 293.68 & 168.62 & 61.13 & 42.54 & 28.40 \\
\hline $\begin{array}{l}\text { Overall budget balance } \\
\text { including grants ( } \% \text { of GDP) }\end{array}$ & -1.56 & -0.85 & -1.99 & -0.08 & -1.90 & -1.80 & -1.20 \\
\hline $\begin{array}{l}\text { Money and quasi money } \\
\text { growth (annual \%) }\end{array}$ & 111.36 & 276.00 & 132.65 & 219.27 & 58.86 & 53.52 & 56.81 \\
\hline $\begin{array}{l}\text { Current account balance } \\
(\% \text { of GDP) }\end{array}$ & -6.09 & -6.66 & -1.60 & -2.54 & -3.51 & -2.64 & -3.00 \\
\hline Net capital account (mln.USD) & 133.20 & 170.10 & 60.40 & 69.40 & 56.30 & 52.70 & 68.9 \\
\hline External debt, total (mln.USD) & 1171.20 & 10110 & 886 & 898 & 1142 & 1439 & 1438 \\
\hline $\begin{array}{l}\text { Exchange rate (BYB/USD, } \\
\text { end of the period) }\end{array}$ & 30.74 & 220.00 & 320.00 & 1180.00 & 1580.00 & 1920.00 & 2156.00 \\
\hline \multicolumn{8}{|c|}{ Kazakhstan } \\
\hline GDP growth (annual \%) & 1.70 & -1.90 & 2.70 & 9.80 & 13.50 & 9.80 & 9.20 \\
\hline Inflation (annual \%) & 17.39 & 7.12 & 8.31 & 13.16 & 8.36 & 5.85 & 6.80 \\
\hline $\begin{array}{l}\text { Overall budget balance } \\
\text { (\% of GDP) }\end{array}$ & -3.58 & -8.10 & -5.20 & -1.00 & -0.90 & 0.30 & -0.90 \\
\hline $\begin{array}{l}\text { Money and quasi money } \\
\text { growth (annual \%) }\end{array}$ & 24.06 & -14.13 & 84.37 & 44.96 & 40.20 & 30.06 & 29.27 \\
\hline $\begin{array}{l}\text { Current account balance } \\
(\% \text { of GDP) }\end{array}$ & -3.61 & -5.53 & -1.01 & 3.69 & -5.01 & -2.82 & -0.23 \\
\hline $\begin{array}{l}\text { Net capital account } \\
\text { (mln USD) }\end{array}$ & -439.80 & -369.10 & -234.00 & -290.60 & -194.02 & -119.90 & -28.79 \\
\hline External debt, total (mln. USD) & 4078.00 & 9932.00 & 12081.40 & 12685.40 & 15158.20 & 18201.30 & 22859.00 \\
\hline $\begin{array}{l}\text { Exchange rate (KZT/USD, } \\
\text { end of the period) }\end{array}$ & 75.55 & 83.80 & 138.20 & 144.50 & 150.94 & 155.85 & 144.22 \\
\hline \multicolumn{8}{|c|}{ Russia } \\
\hline GDP growth (annual \%) & 0.90 & -4.90 & 5.40 & 9.00 & 5.00 & 4.30 & 7.3 \\
\hline Inflation (annual \%) & 14.74 & 27.67 & 85.68 & 20.75 & 21.49 & 15.79 & 15.10 \\
\hline $\begin{array}{l}\text { Overall budget balance, } \\
\text { Including grants ( } \% \text { of GDP) }\end{array}$ & -6.50 & -8.24 & -3.10 & 3.10 & 2.70 & 0.60 & 1.10 \\
\hline $\begin{array}{l}\text { Money and quasi money } \\
\text { growth (annual \%) }\end{array}$ & 27.96 & 37.47 & 56.64 & 58.42 & 36.08 & 33.93 & 38.54 \\
\hline $\begin{array}{l}\text { Current account balance } \\
\text { (\% of GDP) }\end{array}$ & -0.02 & 0.08 & 12.56 & 18.04 & 10.83 & 8.63 & 8.28 \\
\hline Net capital account (bln.USD) & -0.79 & -0.38 & -0.33 & 10.95 & -9.35 & -12.39 & -0.99 \\
\hline External debt, total (bln.USD) & 127.62 & 185.66 & 177.10 & 158.30 & 150.40 & 153.20 & 182.10 \\
\hline $\begin{array}{l}\text { Exchange rate (RUR/USD), } \\
\text { end of the period }\end{array}$ & 5.96 & 20.65 & 27.00 & 28.16 & 30.14 & 31.78 & 29.45 \\
\hline
\end{tabular}

Source: the Ministry of Finance of Belarus, the Ministry of Finance of Kazakhstan, the Ministry of Finance of Russia, World Development Indicator (2004), IFS (2004), EBRD Transition Report (2004) 


\section{References}

Bank of Russia (1998, 1999, 2000, 2001, 2002, 2003, 2004) Annual report for 19972003, Moscow, Russia

Buiter, W.H. (1996) Aspects of Fiscal Performance in some Transition Economies Under Fund-Supported Programs, IMF, Working Paper WP/97/31

Casella, A. (1992) Participation in a Currency Union. The American Economic Review, 82(4), 842-863

Click, W.R. (1998) Seigniorage in a Cross-Section of Countries. Journal of Money, Credit, and Banking, 30 (2), 154-171

Cukierman, A., Edwards, S., and Tabellini, G. (1989) Seigniorage and Political Instability. NBER Working Paper, No. 3199

Cukierman, A. (1992) Central Bank Independence and Monetary Control. Economic Journal, 104, 1437-1448

Cukierman, A. (1998) Central Bank Strategy, Credibility, and Independence: Theory and Evidence. Cambridge, MA: The MIT Press

Cukrowski, J., and Janecki, J. (1998) Financing Budget Deficits by Seigniorage: the Case of Poland 1990-1997. Studies and Analyses No. 155, Center for Social and Economic Research (CASE), Warsaw

Cukrowski, J., and Stavrev, E. (2001) Central Bank Seigniorage in the Czech Republic. Applied Economics Letters, 8, 243-237

Cukrowski, J., and Fischer, M. (2002) Seigniorage Wealth and Redistribution in Central and Eastern European Countries. Post-Communist Economies, 15 (2), 27-46

Cukrowski, J. (2004) Russian Oil: the Role of the Sector in Russia's Economy. PostCommunist Economies, 16 (3), 285-296

De Haan, J., Zelhorst, D., and Roukens, O. (1993) Seigniorage in Developing Countries. Applied Financial Economics, 3, 307-314

Drazen, A. (1985) A General Measure of Inflation Tax Revenues. Economic Letters, 17, $327-330$ 
Drazen, A. (1989) Capital Controls and Seignorage in an Open Economy. In de Cecco M., Giovannini A. (eds.), A European Central Bank? Perspectives on Monetary Unification After Ten Years of the EMS. Cambridge: Cambridge University Press.

European Bank for Reconstruction and Development: Transition Report 2004

Feige, E., Faulend, M., Sonje, V., and Sosic, V. (2000) Currency substitution, unofficial dollarisation and estimates of foreign currency held abroad: the case of Croatia. Paper presented at the Sixth Dubrovnik Economic Conference, Dubrownik, June, 28-29

Feist, H. (2001) The Enlargement of the European Union and the Redistribution of Seigniorage Wealth. CESifo Working Paper, no. 408, Centre of European Studies, IFO Institute for Economic Research, Munich

Fischer, S. (1982) Seigniorage and the Case for a National Money. Journal of Political Economy, 90, 295-313

Friedman, M. (1971) Government Revenue from Inflation. Journal of Political Economy, $79,846-56$

Government of the Republic of Kazakhstan (2003) The Government Decree on the Concept of Financial Sector Development of the Republic of Kazakhstan of July 28, 2003, No. 753. Astana, Kazakhstan (in Russian)

Grilli, V., Masciandaro, D., and Tabellini, G. (1991) Political and Monetary Institutions and Public Financial Policies in the Industrial Countries. Economic Policy, No. 13

Hanson, P. (2003) Can the Russian Economy Keep On Growing? Occasional paper 12, The Center for Research into Post-Communist Economies

Haslag, J. (1998) Seigniorage Revenue and Monetary Policy. Economic Review, third quarter, Federal Reserve Bank of Dallas

Hochreinter, E., Rovelli, R. and Winckler, G. (1996) Central Banks and Seigniorage: a Study of three Economies in Transition. European Economic Review (Papers and Proceedings), 40, 629-643

Honohan, P. (1996) Does it Matter How Seigniorage is Measured? Applied Financial Economics, 6, 293-300 
Horrendorf, B. (1997) Time Consistent Collection of Optimal Seigniorage: a Unifying Framework. Journal of Economic Surveys, 11 (1), 1-41

International Monetary Fund (2004) Belarus: Country Report, No. 04/141

Klein, M., and Neumann, M.J.M. (1990) Seigniorage: What is It and Who Gets It? Weltwirtschaftliches Archiv, 126, 205-221

Koreshkova, T. (2003) A Quantitative Analysis of Inflation As a Tax on the Underground Economy. Unpublished manuscript

Liberati, P. (2001) Poverty and Monetary Transfers in Belarus. Some options for gradual reforms. Economics of Transition, 9 (1), 174-203

Maliszewski, W. (2000) Central Bank Independence. CASE Foundation, Studies \& Analysis, No.120

Markiewicz, M. (2000) Quasi-fiscal operations in the central banks in transition economies. Unpublished manuscript

National Bank of Kazakhstan (1998, 1999, 2000, 2001, 2002, 2003, 2004), Annual report for 1997-2003, Almaty, Kazakhstan

National Bank of the Republic of Belarus (1998, 1999, 2000, 2001, 2002, 2003, 2004), Annual report for 1997-2003, Minsk, Belarus

Neumann, M.J.M. (1996) A Comparative Study of Seigniorage: Japan and Germany. Bank of Japan Monetary and Economic Studies, 14 (1), 104-142

Sargent, T. J., Wallace, N. (1981) Some Unpleasant Monetarist Arithmetics, Federal Reserve Bank of Minneapolis, Quarterly Review, 5, 1-17

Schneider, F. (2002) The size and Development of the Shadow Economies of 22 Transition and 21 OECD Countries. IZA Discussion paper, No. 514

Schobert, F. (2001) Seigniorage: an Argument for a National Currency? CEPR Working Documents, No.174

Sinn, W., Feist, H. (1997) Eurowinners and Eurolosers: the Distribution of Seigniorage Wealth in EMU. European Journal of Political Economy, 13, 665-689

Sinn, W., Feist, H. (2000) Seigniorage Wealth in the Eurosystem: Eurowinners and Eurolosers Revisited. CESifo Working paper, no. 353, Centre for Economic Studies, IFO Institute for Economic Research, Munich 
Summit of the CIS leaders in Yalta, (2003) Agreement on the Establishment of the Common Economic Area of September 19, 2003, draft (in Russian)

Summit of the CIS leaders in Yalta, (2003) Concept on the Establishment of the Common Economic Area of September 19, 2003, draft (in Russian) 
Individual researchers, as well as the on-line and printed version of the CERGE-EI Working Papers Series (including their dissemination) were supported from the following institutional grants:

- Economic Aspects of EU and EMU Entry [Ekonomické aspekty vstupu do Evropské unie a Evropské měnové unie], No. AVOZ70850503, (2005-2010);

- Economic Impact of European Integration on the Czech Republic [Ekonomické dopady evropské integrace na ČR], No. MSM0021620846, (2005-2011);

Specific research support and/or other grants the researchers/publications benefited from are acknowledged at the beginning of the Paper.

(c) Ainura Uzagalieva, 2005

All rights reserved. No part of this publication may be reproduced, stored in a retrieval system or transmitted in any form or by any means, electronic, mechanical or photocopying, recording, or otherwise without the prior permission of the publisher.

Published by

Charles University in Prague, Center for Economic Research and Graduate Education (CERGE) and

Economics Institute (EI), Academy of Sciences of the Czech Republic

CERGE-El, Politických vězñu 7, 11121 Prague 1, tel.: +420 224005 153, Czech Republic.

Printed by CERGE-EI, Prague

Subscription: CERGE-El homepage: http://www.cerge-ei.cz

Editors: Directors of CERGE and EI

Managing editors: Deputy Directors for Research of CERGE and EI

ISSN 1211-3298

ISBN 80-7343-047-9 (Univerzita Karlova v Praze, CERGE)

ISBN 80-7344-036-9 (Národohospodářský ústav AV ČR, Praha) 
CERGE-EI

P.O.BOX 882

Politických vězňů 7

11121 Praha 1

Czech Republic http://www.cerge-ei.cz 